\title{
What goes wrong with the allocation of domestic and international resources for HIV?
}

\section{Olivier Sterck ${ }^{1}$}

\author{
${ }^{1}$ Department of Economics, Oxford University, Oxford, United Kingdom \\ Corresponding author: Olivier Sterck, Department of Economics, Manor Road Building, Manor \\ Road, Oxford, OX1 3UQ, United Kingdom; Email: olivier.sterck@economics.ox.ac.uk; Tel: +44 \\ 7826677594
}

This paper examines how domestic and international financing for HIV is, and ought to be, distributed. We build a theoretical framework that decomposes domestic and international financing for HIV into non-linear functions of national income, HIV prevalence and government effectiveness. We test this model, paying particular attention to non-linearities and to problems of bad controls, multicollinearity and reverse causality. Finally, we use the fitted values of quartile regressions to study how much countries could reasonably pay domestically, and how much they should receive from donors. Worryingly, countries with higher financial means receive on average more aid per PLHIV than very poor ones, and countries with higher HIV prevalence receive on average less aid per PLHIV. The normative analysis concludes that US $\$ 3.08$ billion of fiscal space could be created in LIC and MIC. We identify the countries which could be allocated more aid.

Keywords: HIVIAIDS; financing; government health expenditures; aid; regression analysis

Word count: abstract $(142)$, main text $(4,924)$, references $(1,013)$

Figures: 5

Tables: 3 


\section{Introduction}

Antiretroviral treatment (ART) fundamentally changed the nature of the HIV epidemic, which has shifted from a medical emergency towards a chronic condition with significant and relatively predictable costs. In a handful of high-prevalence and low-income countries, the costs of treatment and prevention are of macro significance to the economy (Atun et al., 2016; Stover et al., 2016; Collier et al., 2015; Lule and Haacker, 2011). UNAIDS estimates that HIV investments in low and middle-income countries should increase from US $\$ 19.2$ billion per year to US $\$ 26$ billion by 2020 to "end the AIDS epidemic as a public health threat by 2030" (Stover et al., 2016).

Considerable investments in prevention are crucial to minimise this financial liability (Schwartländer et al., 2011; UNAIDS, 2014), and achieve the so-called "end of AIDS" (Stover et al., 2016). However, as in a "prisoner dilemma", governments of donor and high-prevalence countries have the incentive to free-ride on the financing of HIV programmes and to underfund prevention, putting the sustainability of HIV response at risk (Collier et al., 2015).

Understanding financial responsibilities of both governments and donors is, therefore, crucial. International financing for HIV - which, in 2015, represented 43\% of funding (UNAIDS, 2016a) - has stagnated since the banking crisis of 2008/09 (Dieleman et al., 2016). The share of external financing in total expenditures for HIV varies considerably across countries, and the allocation of aid for HIV - and for health, more generally - suffers from a lack of transparency, predictability and accountability (Piot et al., 2015).

This paper not only studies how domestic and international funding for HIV is distributed, but also how it ought to be distributed. Our contribution to the literature is conceptual and methodological.

Conceptually, the paper combines descriptive and normative analyses, building on a theoretical framework that decomposes the primary determinants of domestic and international financing for HIV. The descriptive analysis uses multivariate regression analysis 
to study these determinants empirically, focusing on national income, HIV prevalence and government effectiveness broadly defined. In contrast, the normative analysis determines in which countries domestic and international financing for HIV could be increased.

Methodologically, we improve the empirical literature on domestic ${ }^{1}$ and international ${ }^{2}$ financing for HIV by (i) studying non-linearities in functional forms, (ii) excluding "bad controls" and multicollinear variables from the list of regressors, and (iii) using an IV strategy to mitigate the risk of reverse causality between financing and HIV prevalence on the one hand, and between domestic and international financing on the other.

Descriptive studies on domestic financing for HIV are scarce (Ávila et al., 2013; Katz et al., 2014; Vassall et al., 2013). Our econometric analysis shows that domestic financing per people living with HIV (PLHIV) is negatively correlated with HIV prevalence and positively correlated with national income, consistent with results from Ávila et al. (2013). In contrast to their analysis, which is subject to multicollinearity problems between policy indicators, our analysis identifies a strong positive and non-linear relationship between domestic financing for HIV and government effectiveness. The $\mathrm{R}^{2}$ from the regressions are high but far from perfect, suggesting that some countries could be free-riding on the international community in their domestic financing of HIV. We, therefore, explore how much countries could be expected to pay given their characteristics.

Normative analyses on how much countries should pay domestically have followed two routes of enquiry. First, the approach of Resch et al. (2015), recently expanded by Remme et al. (2016), proposes to define quantitative objectives that countries ought to achieve, for example in terms of percentage of government expenditures allocated to health and percentage of health expenditures allocated to HIV. Second, Galárraga et al. (2013) and Remme et al. (2016) used econometric analysis to explore how much fiscal space for HIV governments could

\footnotetext{
${ }^{1}$ See Ávila et al. (2013), Galárraga et al. (2013), Katz et al. (2014), Remme et al. (2016), Resch et al. (2015), Vassall et al. (2013).

${ }^{2}$ See Fan et al. (2013), Gaibulloev and Sandler (2011), Haacker (2009).
} 
create domestically through different channels, such as borrowing, taxation, prioritisation or efficiency gains. In line with the principle of country ownership (OECD, 2005), we propose a third approach, which is more general, and let countries determine their best way to raise domestic expenditures for HIV. Using a quantile regression excluding indicators of government effectiveness and channels of funding, we identify countries (mostly from the middle-income category) which could increase domestic financing. We calculate that US\$3.08 billion of fiscal space could be created if all countries were aligned to (or above) the quartile regression line. This would free up some US\$1.16 billion of international financing for HIV, which could then be re-allocated to other countries.

The empirical literature on international financing for HIV has been rather limited and mainly descriptive. We extend the literature by considering aggregate aid flows towards all low and middle-income countries for which data is available. Our analysis shows that a large share of the variation in funding per PLHIV remains unexplained. We identify a hump-shaped relationship between international funding for HIV per PLHIV and national income, and a negative relationship with HIV prevalence. These results call for more transparency and better coordination in funding allocation. We, therefore, study how donor funding could be better allocated.

To the best of our knowledge, our study is the first to examine how much aid for HIV countries could expect to receive according to their national income, HIV prevalence and policy environment. By using predicted values from a quartile regression, we identify a list of countries which could claim more donor funding according to these criteria.

\section{Method}

We use econometrics to study domestic and international funding for HIV. We follow a descriptive and a normative approach. The descriptive approach explores the determinants of domestic and international financing for HIV. In contrast, the normative approach studies what domestic and international financing for HIV ought to be. 


\section{Conceptual framework}

Domestic financing for HIV is expected to be a function of GDP per capita, HIV prevalence, government effectiveness broadly defined, and international financing. In line with Worldwide Governance Indicators published by the World Bank, government effectiveness "captures perceptions of the quality of public services, the quality of the civil service and the degree of its independence from political pressures, the quality of policy formulation and implementation, and the credibility of the government's commitment to such policies" (Kaufmann et al., 2011). Mathematically, domestic expenditures per people living with HIV (PLHIV) can be decomposed as follows:

$$
\frac{\text { Domestic }}{\text { PLHIV }}=\frac{\text { Domestic }}{G D P} \times \frac{G D P}{\text { Population }} \times \frac{\text { Population }}{\text { PHIV }}=\frac{\frac{\text { Domestic }}{G D P} \times G D P \text { p.c }}{H I V \text { prev. }}
$$

Taking the log on each side, we obtain:

$$
\log \left(\frac{\text { Domestic }}{\text { PLHIV }}\right)=\log \left(\frac{\text { Domestic }}{G D P}\right)+\log (G D P \text { p.c. })-\log (\text { HIV prev. })
$$

The first term on the right-hand side of equation 2, the log of domestic expenditures as a share of GDP, should be further analysed. Domestic expenditures as a share of GDP are expected to depend on several factors.

First, government effectiveness should increase the capacity to raise taxes to finance global public goods, such as investment in health. Government effectiveness could also enhance efficiency, implying that inputs for HIV prevention and treatment can be converted into health outcomes at a lower cost. ${ }^{3}$ Whichever of the two mechanisms prevails is an empiricle question and is anwered below.

\footnotetext{
${ }^{3}$ We thank an anonymous referee for pointing out this mechanism to us.
} 
Second, higher HIV prevalence implies higher needs. This should positively affect domestic expenditures as a share of GDP. Furthermore, resource mobilisation for HIV by political actors should be facilitated in high-prevalence countries.

Third, the impact of GDP on domestic expenditures as a share of GDP is ambiguous. On the one hand, GDP is at the denominator of the ratio, implying that an increase in GDP should reduce the ratio. On the other hand, the cost of prevention and treatment is expected to be higher in richer countries.

Finally, international aid flows for HIV could also affect domestic expenditures. The direction and the importance of this relationship are, however, uncertain: while counterpart financing rules imposed by major donors, such as the Global Fund to Fight AIDS, Tuberculosis and Malaria (the Gobal Fund), and the President's Emergency Plan for AIDS Relief (PEPFAR), should favour co-financing, free-riding from governments should induce an inverse relationship between the two variables.

These effects are summarised in equation 3:

$$
\begin{aligned}
\log \left(\frac{\text { Domestic }}{\text { PLHIV }}\right) & \\
& =f(\overbrace{\text { gov.effect. }}^{?}, \overbrace{\text { HIV prev. }}^{+} \overbrace{\text { GDP p.c. }}^{+}, \overbrace{\text { International }}^{?})+\log (\text { GDP p.c. }) \\
& -\log (\text { HIV prev. })
\end{aligned}
$$

The predictors of international expenditures for HIV are likely to be similar. PEPFAR is the largest contributor to international financing for HIV, providing $42 \%$ or external funding (Dieleman et al., 2016; Dieleman et al., 2016). There is limited information in the public domain on the criteria used to allocate PEPFAR funding (Biesma et al., 2009). Regressions indicate that the two main predictors of PEPFAR funding are (i) the absolute number of adults aged 15 and older living with HIV, and (ii) having designation as a PEPFAR 'focus country' (Fan et al., 
2013). The rationale underlying the selection of focus countries is unclear, as neither the US Congress nor PEPFAR have provided explicit criteria for funding allocation decisions. The Global Fund is the second largest contributor (16\%). The eligibility and allocation rules of the Global Fund are mainly based on GNI per capita and HIV prevalence, although other considerations, including past programme performance and absorptive capacity, are also taken into account. International funding is likely to be positively correlated with government effectiveness (Easterly, 2003). Both PEPFAR and the Global Fund have defined a counterpart financing rule to encourage domestic financing (Vassall et al., 2013).

These considerations are summarised in the following equation:

$$
\log \left(\frac{\text { International }}{\text { PLHIV }}\right)=g(\overbrace{\text { GDP p.c. }}^{-}, \overbrace{\text { HIV prev. }}^{+}, \overbrace{\text { gov.effect. }}^{+}, \overbrace{\frac{\overbrace{\text { Pomestic }}}{\text { PLHIV }}}^{+})
$$

\section{Descriptive analysis}

In line with equations 3 and 4 , the descriptive approach proposes to estimate the following equations using ordinary least-squares (OLS) regression:

$$
\log \left(\frac{\text { Domestic }}{\text { PLHIV }}\right)=\beta_{0}+\beta_{1} \log (G D P \text { pc })+\beta_{2} \log (\text { HIV prev. })+
$$

$\beta_{3}$ gov.effect. $+\beta_{4} \log \left(\frac{\text { International }}{\text { PLHIV }}\right)+\varepsilon$

$$
\log \left(\frac{\text { International }}{\text { PLHIV }}\right)=\beta_{0}+\beta_{1} \log (G D P p c)+\beta_{2} \log (\text { HIV prev. })+
$$

$\beta_{3}$ gov.effect. $+\beta_{4} \log \left(\frac{\text { Domestic }}{\text { PLHIV }}\right)+\varepsilon$

We also consider total financing for HIV per PLHIV as an alternative dependent variable, as well as the share of financing coming from domestic sources. As these two variables are functions of domestic and international financing, they should depend on the same factors. With these dependent variables, we avoid controlling for domestic and international financing in order to avoid perfect multicollinearity between dependent and explanatory variables. 
Thanks to the properties of logarithms, the results are similar if the dependent variables are expressed in per capita terms, except for the coefficient associated with HIV prevalence (log), which is exactly one unit larger (see Appendix for more details).

To estimate this model, we constructed a cross-sectional dataset combining information on domestic and international financing for HIV, GDP per capita, HIV prevalence and government effectiveness. Depending on the specification, data is available for 80 to 91 developing countries (see Appendix for the list of countries).

We improve existing studies on domestic ${ }^{4}$ and international ${ }^{5}$ expenditures for HIV by (i) studying non-linearities, (ii) excluding "bad controls" and multicollinear variables from the list of regressors, and (iii) using an IV strategy to mitigate the risk of reverse causality between financing and HIV prevalence on the one hand, and between domestic and international financing on the other hand.

First, as the functional forms of $f$ and $g$ in equations 3 and 4 are unknown, we test for the presence of non-linearities by including the square of explanatory variables.

Second, variables pertaining to governments' decisions, such as the ratio $\frac{\text { Domestic }}{G D P}$, or tax and debt rates, are excluded from the list of regressors since these variables are intermediate outputs in our causal chain, and are therefore "bad controls" (Angrist and Pischke, 2008). We consider only one measure of government effectiveness to avoid problems of multicollinearity.

Finally, reverse causality could bias the estimates. On the one hand, there could be a twoway relationship between financing for HIV and HIV prevalence. To mitigate reverse causality bias, we follow the work of Oster (2012) and instrument HIV prevalence by the distance to the origin of the HIV virus. ${ }^{6}$ The Angrist-Pischke multivariate $F$ test of excluded instruments ( $p$ -

\footnotetext{
${ }^{4}$ Ávila et al., (2013), Galárraga et al. (2013), Remme et al. (2016).

5 .See Fan et al. (2013), Gaibulloev and Sandler (2011), Haacker (2009).

${ }^{6}$ The fact that the dependent variable is expressed in per PLHIV has no impact on the validity of the instruments used in this paper (see Appendix). Indeed, thanks to properties of logarithms, results are similar if the dependent variable is expressed in per capita terms, except for the coefficient associated with HIV prevalence (log), which becomes one unit larger.
} 
value $<0.01$ ), the Kleibergen-Paap Wald rk F statistic ( $p$-value<0.01), and the Kleibergen-Paap Wald F statistics (F-stat>Stock-Yogo weak ID test critical value for $10 \%$ maximal IV size) confirm that the first-stage regression is not weak and not underidentified (Tables 2, and B.1 in Appendix).

On the other hand, there could be a two-way relationship between domestic and international finance for HIV. PEPFAR and the Global Fund indeed have defined counterpart financing rules linking domestic and international financing. Possible free-riding by governments and donors (Collier et al., 2015) could, however, induce a negative correlation between these variables. We combine two strategies to mitigate reverse causality bias. First, domestic and international expenditures for HIV per PLHIV are lagged by three years when used as explanatory variables, as is commonly performed in the literature (e.g. Clemens et al., 2012; Green et al., 2005). Second, because this first strategy is imperfect (Reed, 2015), we instrument for international expenditures for HIV per PLHIV using a dummy identifying PEPFAR 'focus countries'. As explained by Fan et al. (2013), the "US Congress's past designation of 'focus countries' is a major predictor of PEFPAR funding, though the rationale underlying the selection process for focus countries is unclear." Because it is a major predictor of international aid, although for unclear reasons, past categorisation as 'focus countries' is expected to be a strong instrument satisfying the exclusion restriction. The Angrist-Pischke multivariate $\mathrm{F}$ test of excluded instruments ( $p$-value<0.01), the Kleibergen-Paap Wald rk F statistic ( $p$ value $<0.01$ ), and the Kleibergen-Paap Wald F statistics (F-stat>Stock-Yogo weak ID test critical value for $10 \%$ maximal IV size) confirm that the first-stage regression is not weak and not underidentified (Table 2, and B.1 in Appendix). We found no valid instrument for domestic expenditures for HIV per PLHIV. As explained below, this is not expected to be an issue, as our results show that reverse causality is marginal.

Variables of interest are likely to be subject to measurement errors (Kerner et al., 2015). This is especially true for HIV prevalence which is inferred from an epidemiological model (UNAIDS, 2016b). The autocorrelation coefficients of variables of interest are extremely high 
(higher than 0.99 from one year to another for GNI per capita, HIV prevalence and government effectiveness). We, therefore, avoid fixed effects and first difference estimations as these methods are "particularly worrisome when the measurement error is just serially uncorrelated noise, while the signal is highly correlated over time" (Pischke, 2007). These methods indeed "typically increase the variance of the noise relative to the variance of the signal" (Hausman, 2001). Results are robust to the removal of outliers and to quantile regression (see Appendix). All analyses were carried out with STATA/MP 12.

\section{Normative analysis}

For the normative approach, we adapt the regression models of the descriptive approach to examine what financing for HIV ought to be. We distinguish two normative questions: "What amount ought countries pay domestically?" and "Which countries ought to receive more (or less) international funding?"

For the first question, related to domestic financing, we postulate that countries' ability to pay should entirely depend on their national revenue and HIV prevalence. We argue that other factors, such as government effectiveness, fiscal efforts, or health and HIV prioritisation, should not be controlled for in a normative regression. Indeed, we want to predict what countries could ideally pay if their government was effective at raising revenue and allocating these to HIV programmes. Our method proposes to take these latter factors into account indirectly by running a quantile regression. Quantile regression is also useful to minimise the influence of outliers (Galárraga et al., 2013). We determine how much best-behaving countries with similar national revenue and HIV prevalence contribute domestically. We base our analysis on the $75^{\text {th }}$ percentile, in an attempt to find a balance between realism and the scope for creating fiscal space. Regressions based on other percentiles are presented in the Appendix. We estimate the following equation using quartile regression:

$\log ($ domestic exp.per PLHIV $)=\beta_{0}+\beta_{1} \log (G D P$ p.c. $)+\beta_{2} \log ($ HIV prev. $)+\varepsilon$ 
We use the results from this regression to estimate how much countries could be expected to pay domestically. Intuitively, the gap in US\$ between the predicted values of the regression and the actual expenditures for HIV represents the potential increase in domestic funding per PLHIV. We multiply this gap by the number of people living with HIV to obtain an estimate of the fiscal space for HIV that can be created in each country. LIC and MIC should, however, not be expected to pay more for HIV programmes than what is needed to fight their epidemics. Therefore, in estimating fiscal space for HIV, we consider the minimum between the predicted values of the regression and UNAIDS needs estimates (Stover et al., 2016). In line with the normative framework of Collier et al. (2015), we focus here on UNAIDS estimates of the cost of treatment and testing. This assumption leads to lower-bound estimates (we include the cost of prevention in Appendix). We also calculate if such an increase in domestic contribution creates scope for a reallocation of international funding for HIV. Of course, the scope for reallocation of international aid in response to increased domestic financing is necessarily limited to the current amount of international aid provided to the country under scrutiny.

For the second question, regarding the allocation of international financing, we postulate that a sensible allocation of aid for HIV should depend on the financial capacity of recipient countries (as measured by GDP per capita) and on their needs (here, HIV prevalence), but also on government effectiveness and domestic finance for HIV. Past research has indeed suggested that the quality of policy may impact returns on aid (Collier and Dollar, 2002, 2001). Based on this observation, many international actors have decided to allocate funds in function of some measure of government effectiveness (Easterly, 2003). The international community has also shown a willingness to encourage domestic financing by setting up counterpart financing rules (Vassall et al., 2013). We re-estimate equation 6 using a quartile regression $\left(25^{\text {th }}\right.$ percentile), relying on the assumption that countries can at least expect to receive as much aid as the predicted values of quartile regression line. We use the $25^{\text {th }}$ percentile instead of the median regression line because we recognise that donors may have different priorities and objectives in justifying part of the unexplained differences. Regressions with other 
percentiles are presented in Appendix. The residuals and predicted values from this regression can be used to determine which countries could be allocated more aid, and how much they could get.

As for the descriptive analysis, we explore non-linearities, exclude "bad controls" and present results of IV quantile regressions (results in Appendix).

Data

Data was taken from the following sources (Table 1). The sample is described in Appendix.

[Table 1 here]

\section{Results}

\section{Descriptive approach}

The results of OLS and IV estimations of equations 5 and 6 are presented in Table 2. Nonlinearities are explored in Figure 1 and in the Appendix. In line with the conceptual framework, domestic expenditures per PLHIV are increasing in GDP per capita and government effectiveness, and decreasing with HIV prevalence (columns 1 and 2). The estimated elasticity of domestic expenditures with respect to GDP per capita is slightly lower that 1 , but this difference is not statistically significant. A doubling in GDP per capita is, therefore, expected to almost double domestic expenditures per PLHIV, in line with Ávila et al. (2013) and Remme et al. (2016). The estimated elasticity of domestic expenditures with respect to HIV prevalence is -0.4 in the IV model. This coefficient is significantly higher than -1 . This highlights higher revenue mobilisation for HIV in high-prevalence countries, due to higher needs and prioritisation by political actors. This elasticity is, however, significantly lower than 0 , suggesting that increased revenue mobilisation domestically is not sufficient to compensate for the higher needs. The impact of government effectiveness on domestic financing for HIV is also statistically and economically significant. In the IV model, a one-standard-deviation 
improvement in government effectiveness increases domestic expenditures for HIV by $61 \%$. This relationship is non-linear: the impact of an improvement in governance is higher when government quality is initially lower (Figure 1(a) and Appendix). Results from the OLS regression suggest that there could be a positive correlation between domestic and international finance for HIV. The direction of this relationship is, however, questionable given the risk of reverse causality. The coefficient associated with international expenditures per PLHIV becomes statistically insignificant and very close to zero when this variable is instrumented by a dummy identifying PEPFAR 'focus countries'. This suggests that domestic financing is not greatly influenced by international financing for HIV, despite the counterpart financing rules set up by PEPFAR and the Global Fund.

[Table 2 here]

International expenditures for HIV per PLHIV are decreasing in GDP per capita and HIV prevalence, and increasing in government effectiveness (columns 3 and 4). In the conceptual framework, we highlighted that allocation formulas of major donors are not very transparent. Empirically, this is reflected in the very low $\mathrm{R}^{2}$ associated with OLS and IV regressions. The relationship between GDP per capita and international funding per PLHIV is non-linear (Figure 1(b) and Appendix). In Figure 1(b), aid per PLHIV is maximal for GDP per capita equal to US\$1,447. The estimated elasticity of international expenditures with respect to HIV prevalence is -0.31 in the IV model. For similar national income and governance quality, countries with higher HIV prevalence receive less aid per PLHIV. Good governance increases international financing for HIV, although the coefficients of the OLS and IV regressions are not, rather surprisingly, significant. International expenditures seem to be weakly increasing with domestic expenditures. This relationship is insignificant in the IV regression. This relationship is unlikely to be affected by reverse causality, as we found no evidence of a causal link between international and domestic expenditures in column 2.

Results on total funding per PLHIV are in accordance with previous findings (columns 5 and 6). Total funding per PLHIV is weakly increasing with GDP per capita (elasticity $=0.13$ in the 
IV model), increasing with governance effectiveness (in the IV model, a one-standarddeviation increase in government effectiveness induces a 36\% increase in total funding), and decreasing with HIV prevalence (elasticity $=-0.39$ in the IV model).

The share of the response against HIV which is financed domestically depends almost entirely on GDP per capita (columns 7 and 8), in line with Haacker (2009). This relationship is nonlinear. The share financed domestically is flat and about $10 \%$ for low-income countries. This share is then sharply increasing for higher level of GDP per capita: the share is on average about $48 \%$ for countries with GDP per capita equal to US\$4,085, and about $91 \%$ for GDP per capita equal to US $\$ 12,615$ (Figure $1(\mathrm{c}))^{7}$

[Figure $1 \mathrm{a}, \mathrm{b}, \mathrm{c}$ here]

\section{Normative approach}

Estimates of equation 7 are presented in Table 3, columns 1 to 3 . The coefficients of the quartile regression $\left(75^{\text {th }}\right.$ percentile) are not significantly different from the results of the OLS regression, except for the intercept, which is significantly higher. From column 3 , we identify countries which could create fiscal space (Figure 2). We calculate that US\$3.08 billion of fiscal space could be created in LIC and MIC if countries were at least aligned with the quartile regression line. This corresponds to a $64 \%$ increase in domestic financing for HIV in the sample of countries considered. This estimate is in the same order of magnitude as previous estimates from the literature. Considering a sample of 84 countries, Galárraga et al. (2013) concluded that domestic contributions could increase by US\$2.3 billion annually. Resch et al. (2015) concluded that domestic spending could be increased by US\$3 billion annually in their sample of 12 countries. Remme et al. (2016) found that public spending in the 14 most HIV-

\footnotetext{
${ }^{7}$ As of 2013 , the GNI per capita threshold of US\$ 4,085 (in 2012) was separating low-middle and upper-middle income countries, while the threshold of US\$12,615 was separating upper-middle income countries from high-income countries.
} 
affected countries could increase by US $\$ 7.8$ billion per year (this latter estimate is $50 \%$ lower with regression analysis).

[Table 3 here]

If countries did indeed increase domestic spending as indicated, this would free up some US\$1.16 billion of international financing for HIV, which could then be re-allocated to other countries. Most gain would come from reallocating aid away from a handful of MIC - who, our analysis suggests, have scope to increase domestic financing: South Africa (US\$376 million), Nigeria (US\$243 million), Zambia (US\$132 million), Indonesia (US\$50 million), and Mozambique (US\$49 million) (see Appendix for all results). We emphasise that these estimates are only indicative of past behaviour, as data on domestic and international financing are not always available for most recent years.

[Figure 2 here]

Results of quantile regressions with international expenditures for HIV are presented in Table 3, columns 4 to 9 . The square of GDP per capita (log) is included in columns 7 to 9 as this term is highly significant, and its inclusion sharply improves the fit. Based on column 9, we identify 20 countries receiving less aid than the predicted values of the quartile regression. For 12 of these countries, the difference between predicted values and current aid is superior to US\$1 million (Figure 3). Cameroon, for example, could be allocated US\$118.9 per PLHIV, while it currently receives US $\$ 72.7$ per PLHIV. Adjusting international aid to Cameroon would require US $\$ 70.9$ million (a complete list is provided in Appendix).

[Figure 3 here] 


\section{Discussion and conclusion}

From the descriptive analysis, we identify three issues with the current framework of expenditures for HIV. First, a large share of the variation in funding per PLHIV remains unexplained. This is particularly true for international expenditures.

Second, the hump-shaped relationship between international expenditures per PLHIV and GDP per capita seems ethically problematic. This relationship may be partly explained by higher prices in middle-income countries. However, it seems counterintuitive that countries with higher financial means receive more funding per PLHIV than very poor ones.

Third, at similar level of GDP per capita and governance quality, countries with higher HIV prevalence receive less aid per PLHIV. This observation is consistent with the fact that the share of domestic funding for HIV in total funding is only weakly decreasing in HIV prevalence. In the absence of large economies of scale, this allocation of aid seems unethical and inefficient: countries with higher needs ceteris paribus should be expected to receive more aid per PLHIV.

These results call for more transparency and better coordination in funding allocation. However, the allocation of aid by bilateral donors is often influenced by political factors, which are typically hard to influence. Multilateral donors are expected to be more open to revising their allocation criteria, as illustrated by the recent Equitable Access Initiative (EAI), an international initiative to improve decision making on health and development. The GFATM could, therefore, play a more explicit 'balancing' role in the system, compensating countries unduly penalised by bilateral donors (Manning and Sterck, 2017). We also encourage the use of counterpart financing rules to mitigate free-riding and encourage domestic co-financing (Sterck et al., 2017b).

In the normative analysis, we identified countries which could increase domestic expenditures as well as countries which could receive more aid.

Our study and its limitations call for further research and for renewed policy action. 
First, our empirical analysis was restricted to countries for which data is available, and data quality is expected to be imperfect. Efforts to collect high-quality data should be pursued, and the conclusions of this study should be revised when updated data becomes available. The conclusions from this study also need to be complemented by country-by-country analyses.

Second, research is needed to improve information on the scale of unfunded HIV liabilities at the country level. Finance ministers, along with health ministers and the international community, should recognise these liabilities and manage these in a sustainable way. Given the finance dimension involved here, the IMF and the World Bank could play a key role, at least where the size of the liability is macro-significant.

Third, research and policy dialogue are needed to better allocate funding for HIV. Normative frameworks on how to allocate development assistance for health are surprisingly scarce. Allocation frameworks developed for the allocation of aid for development should be adapted to the specificities of health and HIV (see, for example, Collier and Dollar, 2002; Sterck et al., 2017a). Political and economic barriers hindering a better allocation of aid should be identified. Researchers and policy-makers also need to prepare the integration of HIV programmes into universal health coverage without harming donor support and hampering the great successes of the response against HIV.

Finally, a sharp reduction in new infections is the key sustainable solution in the absence of a breakthrough on vaccination or cure. While new HIV infections among children have declined by $50 \%$ since 2010 thanks to the effective prevention of mother-to-child transmission, there has been no decline in new infections among adults since 2010, despite increased ART coverage (UNAIDS, 2016a). On the programmatic side, higher priority is, therefore, needed for biomedical and behavioural approaches to prevention that are known to be effective, and targeted at key populations and hot-spots of HIV transmission (McGillen et al., 2016). On the financing side, research should determine under which conditions financing should be frontloaded - for example, through borrowing or IFFIm-type arrangements - in order to boost investments in cost-reducing prevention programmes. 


\section{References}

Angrist, J.D., Pischke, J.-S., 2008. Mostly harmless econometrics: An empiricist's companion. Princeton university press, Princeton.

Atun, R., Chang, A.Y., Ogbuoji, O., Silva, S., Resch, S., Hontelez, J., Bärnighausen, T., 2016. Long-term financing needs for HIV control in sub-Saharan Africa in 2015-2050: a modelling study. BMJ Open 6, e009656. doi:10.1136/bmjopen-2015-009656

Ávila, C., Loncar, D., Amico, P., De Lay, P., 2013. Determinants of government HIV/AIDS financing: a 10 -year trend analysis from 125 low- and middle-income countries. BMC Public Health 13, 673. doi:10.1186/1471-2458-13-673

Biesma, R.G., Brugha, R., Harmer, A., Walsh, A., Spicer, N., Walt, G., 2009. The effects of global health initiatives on country health systems: a review of the evidence from HIV/AIDS control. Health Policy Plan. czp025. doi:10.1093/heapol/czp025

Clemens, M.A., Radelet, S., Bhavnani, R.R., Bazzi, S., 2012. Counting Chickens when they Hatch: Timing and the Effects of Aid on Growth*. The Economic Journal 122, 590-617. doi:10.1111/j.1468-0297.2011.02482.x

Collier, P., Dollar, D., 2002. Aid allocation and poverty reduction. European Economic Review 46, 1475-1500. doi:10.1016/S0014-2921(01)00187-8

Collier, P., Dollar, D., 2001. Can the World Cut Poverty in Half? How Policy Reform and Effective Aid Can Meet International Development Goals. World Development 29, 1787-1802. doi:10.1016/S0305-750X(01)00076-6

Collier, P., Sterck, O., Manning, R., 2015. The Moral and Fiscal Implications of Anti-Retroviral Therapies for HIV in Africa. CSAE Discussion paper WPS-2015-05.

Dieleman, J., Murray, C.J.L., Haakenstad, A., 2016. Financing Global Health 2015: Development assistance steady on the path to new Global Goals. IHME report.

Dieleman, J.L., Schneider, M.T., Haakenstad, A., Singh, L., Sadat, N., Birger, M., Reynolds, A., Templin, T., Hamavid, H., Chapin, A., Murray, C.J.L., 2016. Development assistance for health: past trends, associations, and the future of international financial flows for health. The Lancet 387, 2536-2544. doi:10.1016/S0140-6736(16)30168-4

Easterly, W., 2003. Can Foreign Aid Buy Growth? The Journal of Economic Perspectives 17, 23-48.

Fan, V., Duran, Denizhan, Glassman, Amanda, Sliverman, Rachel, 2013. The Financial Flows of PEPFAR: A Profile. Center For Global Development, Policy papers.

Gaibulloev, K., Sandler, T., 2011. Aid for AIDS in Africa. Empir Econ 43, 1171-1197. doi:10.1007/s00181-011-0527-3

Galárraga, O., Wirtz, V.J., Santa-Ana-Tellez, Y., Korenromp, E.L., 2013. Financing HIV programming: how much should low- and middle-income countries and their donors pay? PLOS ONE 8, e67565. doi:10.1371/journal.pone.0067565

Green, R.K., Malpezzi, S., Mayo, S.K., 2005. Metropolitan-specific estimates of the price elasticity of supply of housing, and their sources. The American Economic Review 95, 334-339.

Haacker, M., 2009. Financing HIV/AIDS programs in sub-Saharan Africa. Health Aff (Millwood) 28, 1606-1616. doi:10.1377/hlthaff.28.6.1606

Hausman, J., 2001. Mismeasured Variables in Econometric Analysis: Problems from the Right and Problems from the Left. The Journal of Economic Perspectives 15, 57-67.

Katz, I., Routh, S., Bitran, R., Hulme, A., Avila, C., 2014. Where will the money come from? Alternative mechanisms to HIV donor funding. BMC Public Health 14, 956. doi:10.1186/1471-2458-14-956

Kaufmann, D., Kraay, A., Mastruzzi, M., 2011. The Worldwide Governance Indicators: Methodology and Analytical Issues. Hague J Rule Law 3, 220-246. doi:10.1017/S1876404511200046

Kerner, A., Jerven, M., Beatty, A., 2015. Does it pay to be poor? Testing for systematically underreported GNI estimates. Rev Int Organ 1-38. doi:10.1007/s11558-015-9239-3 
Lule, E., Haacker, M., 2011. The Fiscal Dimension of HIV/AIDS in Botswana, South Africa, Swaziland, and Uganda: Experiences from Botswana, South Africa, Swaziland, and Uganda. World Bank Publications, Washington D.C.

Manning, R., Sterck, O., 2017. Rethinking international and domestic financing for HIV in low and middle income countries. Dev Policy Rev n/a-n/a. doi:10.1111/dpr.12232

McGillen, J.B., Anderson, S.-J., Dybul, M.R., Hallett, T.B., 2016. Optimum resource allocation to reduce HIV incidence across sub-Saharan Africa: a mathematical modelling study. The Lancet HIV 3, e441-e448. doi:10.1016/S2352-3018(16)30051-0

OECD, 2005. Paris declaration on aid effectiveness: Ownership, harmonisation, alignment, results and mutual accountability, in: High Level Forum on Joint Progress toward Enhanced Aid Effectiveness: Harmonization, Alignment and Results. 2nd High Level Forum on Aid Effectiveness. Paris, France.

Oster, E., 2012. HIV and sexual behavior change: Why not Africa? Journal of Health Economics 31, 35-49. doi:10.1016/j.jhealeco.2011.12.006

Piot, P., Abdool Karim, S.S., Hecht, R., Legido-Quigley, H., Buse, K., Stover, J., Resch, S., Ryckman, T., Møgedal, S., Dybul, M., Goosby, E., Watts, C., Kilonzo, N., McManus, J., Sidibé, M., 2015. Defeating AIDS-advancing global health. The Lancet 386, 171-218. doi:10.1016/S01406736(15)60658-4

Pischke, S., 2007. Lecture notes on measurement error.

Reed, W.R., 2015. On the Practice of Lagging Variables to Avoid Simultaneity. Oxf Bull Econ Stat 77, 897-905. doi:10.1111/obes.12088

Remme, M., Siapka, M., Sterck, Olivier, Ncube, Mthuli, Vassall, Anna, 2016. Financing the HIV response in sub-Saharan Africa from domestic sources: moving beyond a normative approach. Social Science \& Medicine forthcoming.

Resch, S., Ryckman, T., Hecht, R., 2015. Funding AIDS programmes in the era of shared responsibility: an analysis of domestic spending in 12 low-income and middle-income countries. The Lancet Global Health 3, e52-e61. doi:10.1016/S2214-109X(14)70342-0

Schwartländer, B., Stover, J., Hallett, T., Atun, R., Avila, C., Gouws, E., Bartos, M., Ghys, P.D., Opuni, M., Barr, D., Alsallaq, R., Bollinger, L., de Freitas, M., Garnett, G., Holmes, C., Legins, K., Pillay, Y., Stanciole, A.E., McClure, C., Hirnschall, G., Laga, M., Padian, N., 2011. Towards an improved investment approach for an effective response to HIV/AIDS. The Lancet 377, 2031-2041. doi:10.1016/S0140-6736(11)60702-2

Sterck, O., Roser, M., Ncube, M., Thewissen, S., 2017a. Allocation of development assistance for health: is the predominance of national income justified? Health Policy Plan. doi:10.1093/heapol/czw173

Sterck, O., Roser, M., Thewissen, S., others, 2017b. Turning the paradigm of aid allocation on its head. Centre for the Study of African Economies, University of Oxford.

Stover, J., Bollinger, L., Izazola, J.A., Loures, L., DeLay, P., Ghys, P.D., Group, F.T. modeling working, 2016. What Is Required to End the AIDS Epidemic as a Public Health Threat by 2030? The Cost and Impact of the Fast-Track Approach. PLOS ONE 11, e0154893. doi:10.1371/journal.pone.0154893

UNAIDS, 2016a. Fact Sheet 2016. UNAIDS, Geneva.

UNAIDS, 2016b. Global AIDS Update 2016. UNAIDS, Geneva.

UNAIDS, 2014. Fast-track: ending the AIDS epidemic by 2030. UNAIDS, Geneva.

Vassall, A., Remme, M., Watts, C., Hallett, T., Siapka, M., Vickerman, P., Terris-Prestholt, F., Haacker, M., Heise, L., Haines, A., Atun, R., Piot, P., 2013. Financing Essential HIV Services: A New Economic Agenda. PLOS Med 10, e1001567. doi:10.1371/journal.pmed.1001567 
Variable

Domestic and international expenditures for HIV: we use the most recent data available between 2014 and 2008

HIV prevalence in 2012

GNI per capita in 2012;

Population in 2012

Government effectiveness in 2012
Source

AIDSinfoonline data (accessed $5^{\text {th }}$ April 2017)

http://www.aidsinfoonline.org/devinfo/libraries/aspx/ Home.aspx

IMF data (accessed $1^{\text {st }}$ April 2016)

http://www.imf.org/en/Data

World Bank WGI data (accessed 14 ${ }^{\text {th }}$ February 2016).

http://info.worldbank.org/governance/wgi/index.aspx \#home

Table 1 - data sources 


\begin{tabular}{|c|c|c|c|c|c|c|c|c|}
\hline & (1) & $(2)$ & (3) & $(4)$ & (5) & (6) & (7) & (8) \\
\hline & \multicolumn{6}{|c|}{ Expenditures for HIV per PLHIV (log) } & \multirow{2}{*}{\multicolumn{2}{|c|}{$\begin{array}{l}\text { Share } \\
d /(d+i)\end{array}$}} \\
\hline & \multicolumn{2}{|c|}{ Domestic } & \multicolumn{2}{|c|}{ International } & \multicolumn{2}{|c|}{ Total } & & \\
\hline & OLS & IV & OLS & IV & OLS & IV & OLS & IV \\
\hline GDP p.c. (log) & $\begin{array}{c}0.960 * * * \\
(0.125)\end{array}$ & $\begin{array}{c}0.869 * * * \\
(0.189)\end{array}$ & $\begin{array}{c}-0.671 * * * \\
(0.213)\end{array}$ & $\begin{array}{c}-0.597^{* * *} \\
(0.220)\end{array}$ & $\begin{array}{c}0.170 \\
(0.107)\end{array}$ & $\begin{array}{c}0.126 \\
(0.109)\end{array}$ & $\begin{array}{l}0.221^{* * *} \\
(0.0223)\end{array}$ & $\begin{array}{l}0.224 * * * \\
(0.0223)\end{array}$ \\
\hline HIV prevalence (log) & $\begin{array}{c}-0.283 * * * \\
(0.0674)\end{array}$ & $\begin{array}{c}-0.401 * * * \\
(0.124)\end{array}$ & $\begin{array}{c}-0.107 \\
(0.0770)\end{array}$ & $\begin{array}{l}-0.312^{*} \\
(0.169)\end{array}$ & $\begin{array}{c}-0.243 * * * \\
(0.0531)\end{array}$ & $\begin{array}{c}-0.386 * * * \\
(0.103)\end{array}$ & $\begin{array}{l}-0.0126 \\
(0.0106)\end{array}$ & $\begin{array}{l}-0.00171 \\
(0.0168)\end{array}$ \\
\hline Governement effectiveness & $\begin{array}{l}0.785^{* * *} \\
(0.213)\end{array}$ & $\begin{array}{c}0.818 * * * \\
(0.242)\end{array}$ & $\begin{array}{c}0.203 \\
(0.259)\end{array}$ & $\begin{array}{c}0.183 \\
(0.312)\end{array}$ & $\begin{array}{l}0.496 * * \\
(0.189)\end{array}$ & $\begin{array}{l}0.530 * * \\
(0.210)\end{array}$ & $\begin{array}{c}0.0252 \\
(0.0334)\end{array}$ & $\begin{array}{c}0.0211 \\
(0.0347)\end{array}$ \\
\hline $\begin{array}{l}\text { International expenditures } \\
\text { per PLHIV (log, 3-year lag) }\end{array}$ & $\begin{array}{l}0.216^{* *} \\
(0.0842)\end{array}$ & $\begin{array}{l}-0.0104 \\
(0.412)\end{array}$ & & & & & & \\
\hline $\begin{array}{l}\text { Domestic expenditures } \\
\text { per PLHIV (log, 3-year lag) }\end{array}$ & & & $\begin{array}{l}0.245^{* *} \\
(0.109)\end{array}$ & $\begin{array}{c}0.153 \\
(0.158)\end{array}$ & & & & \\
\hline Constant & $\begin{array}{c}-4.628 * * * \\
(1.204)\end{array}$ & $\begin{array}{l}-3.284 \\
(3.158)\end{array}$ & $\begin{array}{c}9.039 * * * \\
(1.414)\end{array}$ & $\begin{array}{c}7.775 * * * \\
(1.589)\end{array}$ & $\begin{array}{c}3.978 * * * \\
(0.843)\end{array}$ & $\begin{array}{c}3.570 * * * \\
(0.816)\end{array}$ & $\begin{array}{c}-1.354 * * * \\
(0.172)\end{array}$ & $\begin{array}{c}-1.312 * * * \\
(0.174)\end{array}$ \\
\hline Observations & 88 & 83 & 84 & 80 & 91 & 86 & 91 & 86 \\
\hline R-squared & 0.72 & 0.69 & 0.18 & 0.13 & 0.41 & 0.35 & 0.66 & 0.66 \\
\hline First stage F-test (HIV prev.) & & 72 & & 18.51 & & 28.98 & & 28.98 \\
\hline First stage F-test (International/PLHIV) & & 15.2 & & & & & & \\
\hline Kleibergen-Paap rk LM statistic & & 8.02 & & 12.19 & & 17.25 & & 17.25 \\
\hline Kleibergen-Paap rk Wald F statistic & & 7.81 & & 18.51 & & 28.98 & & 28.98 \\
\hline
\end{tabular}

${ }^{*} \mathrm{p}<0.10,{ }^{*} \mathrm{p}<0.05, * * * \mathrm{p}<0.01$. Robust standard errors in parentheses.

Table 2 - regression analysis of the determinants of expenditures for HIV (descriptive approach) 


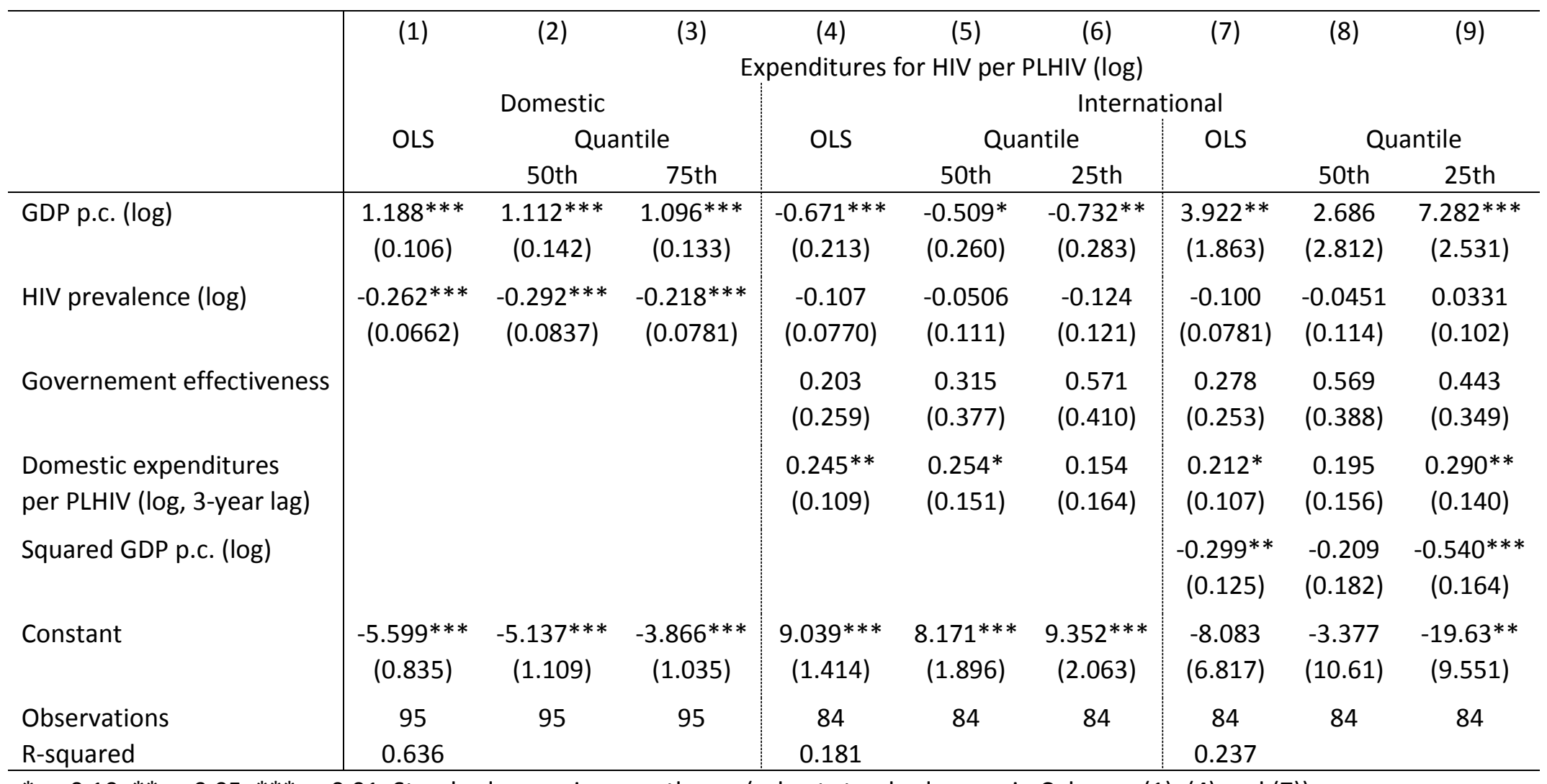

$* \mathrm{p}<0.10, * * \mathrm{p}<0.05, * * * \mathrm{p}<0.01$. Standard errors in parentheses (robust standard errors in Columns (1), (4) and (7))

Table 3 - results of the normative approach 
Figures (colors and black \& white)
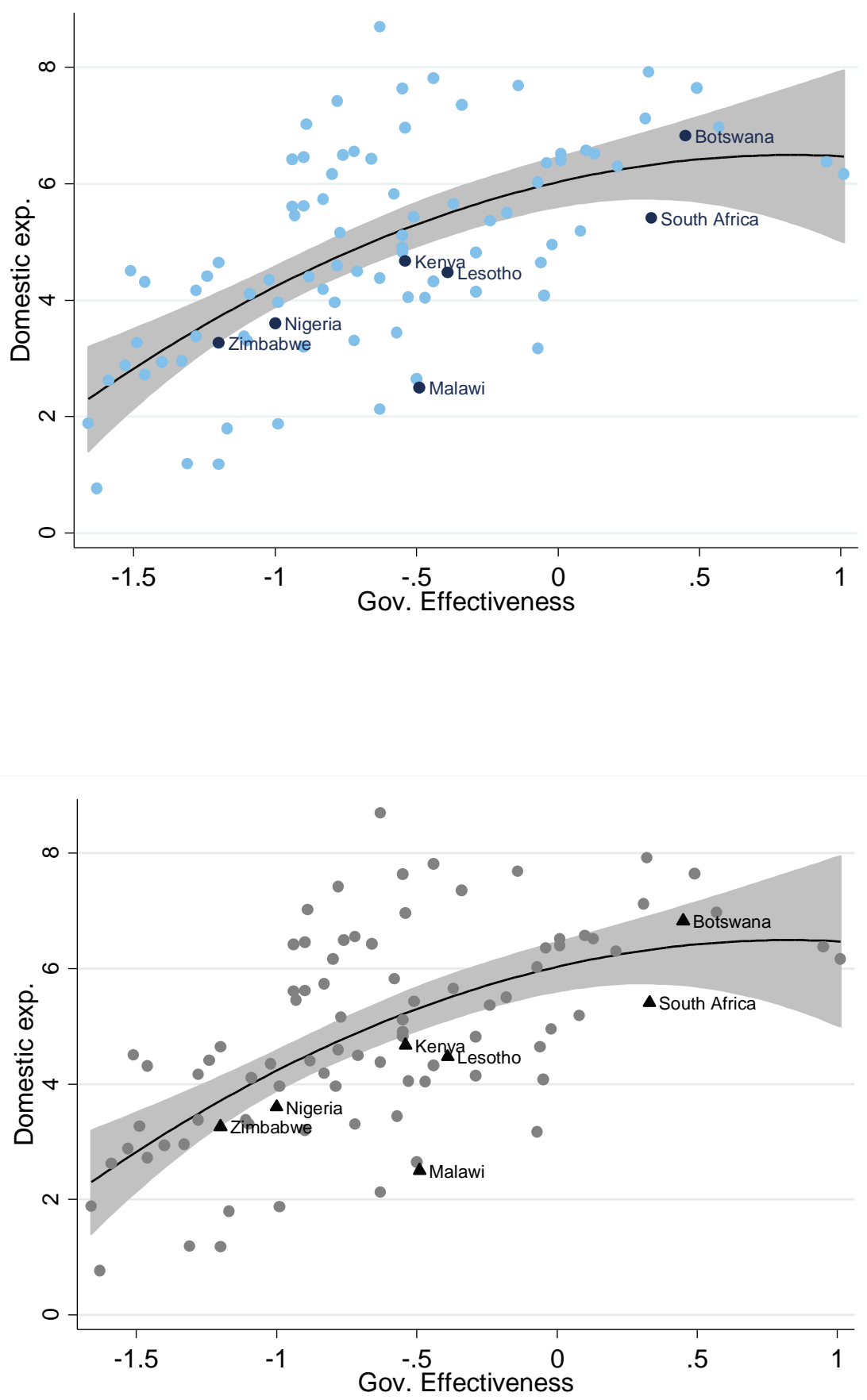

Figure 1 (a) - Domestic expenditures and government effectiveness 

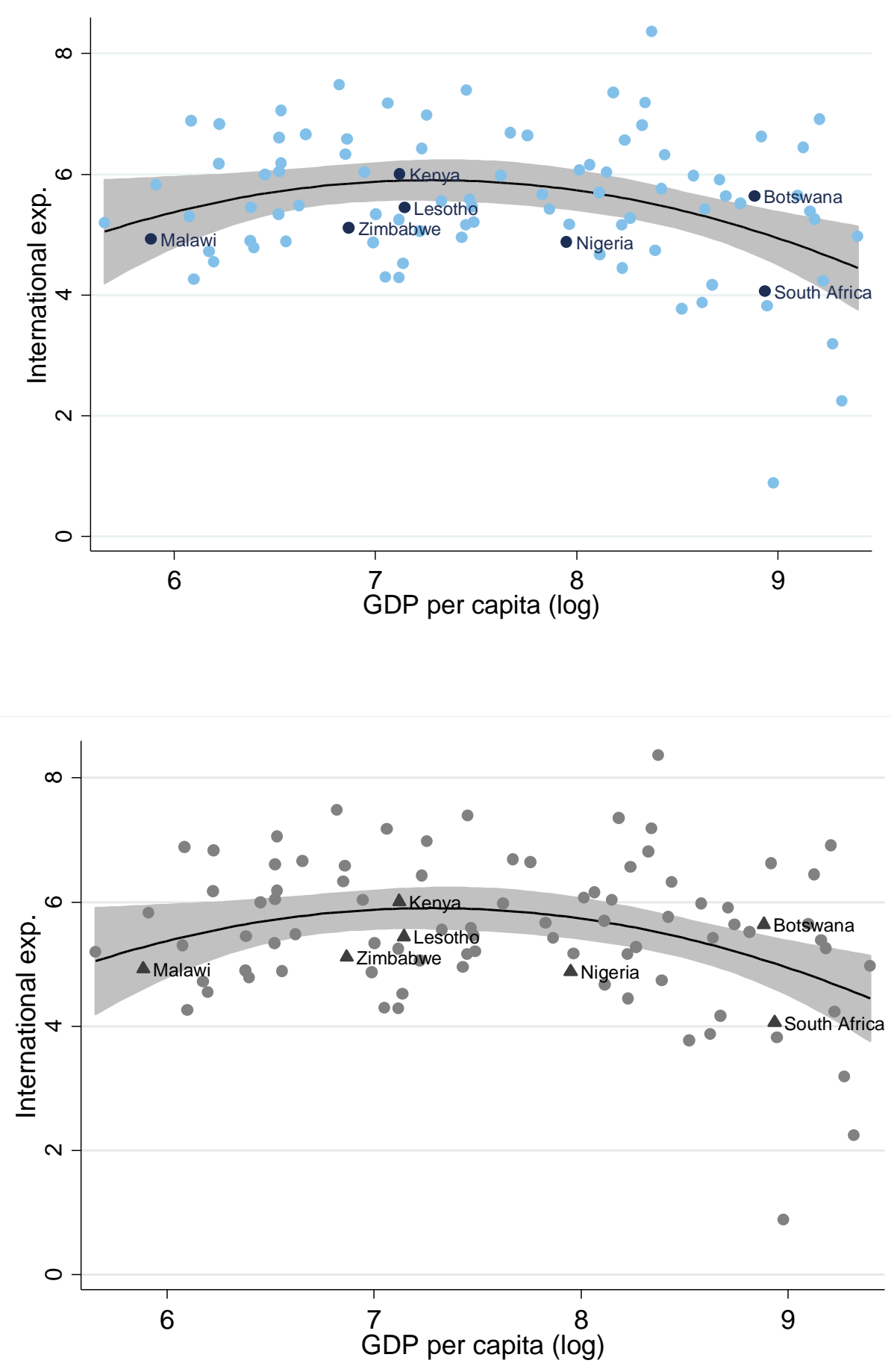

Figure 1 (b) - International expenditures and GDP per capita (log) 

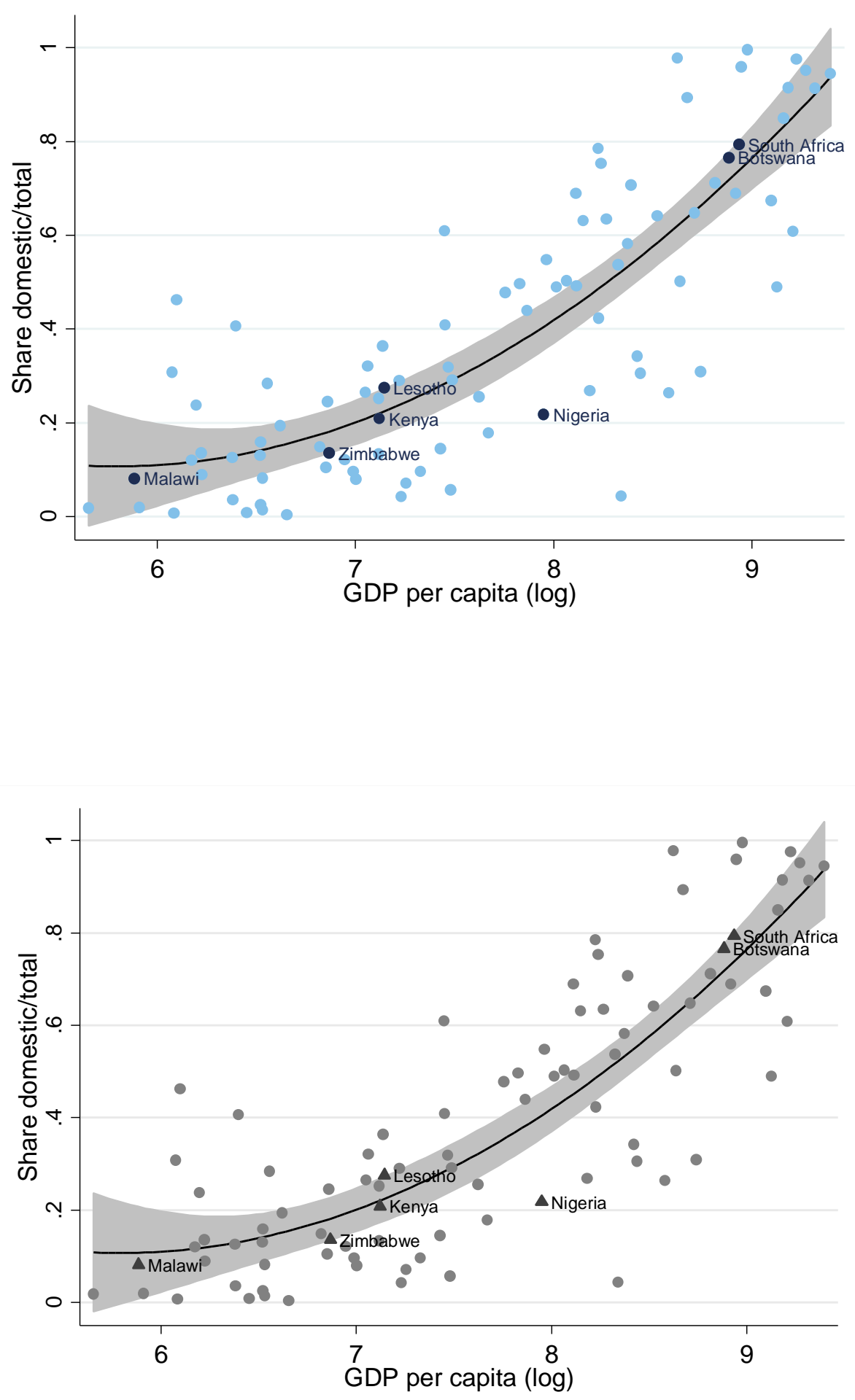

Figure 1(c) - Share domestic/total and GDP per capita (log)

Figure 1: non-linear relationships between variables of interests. 

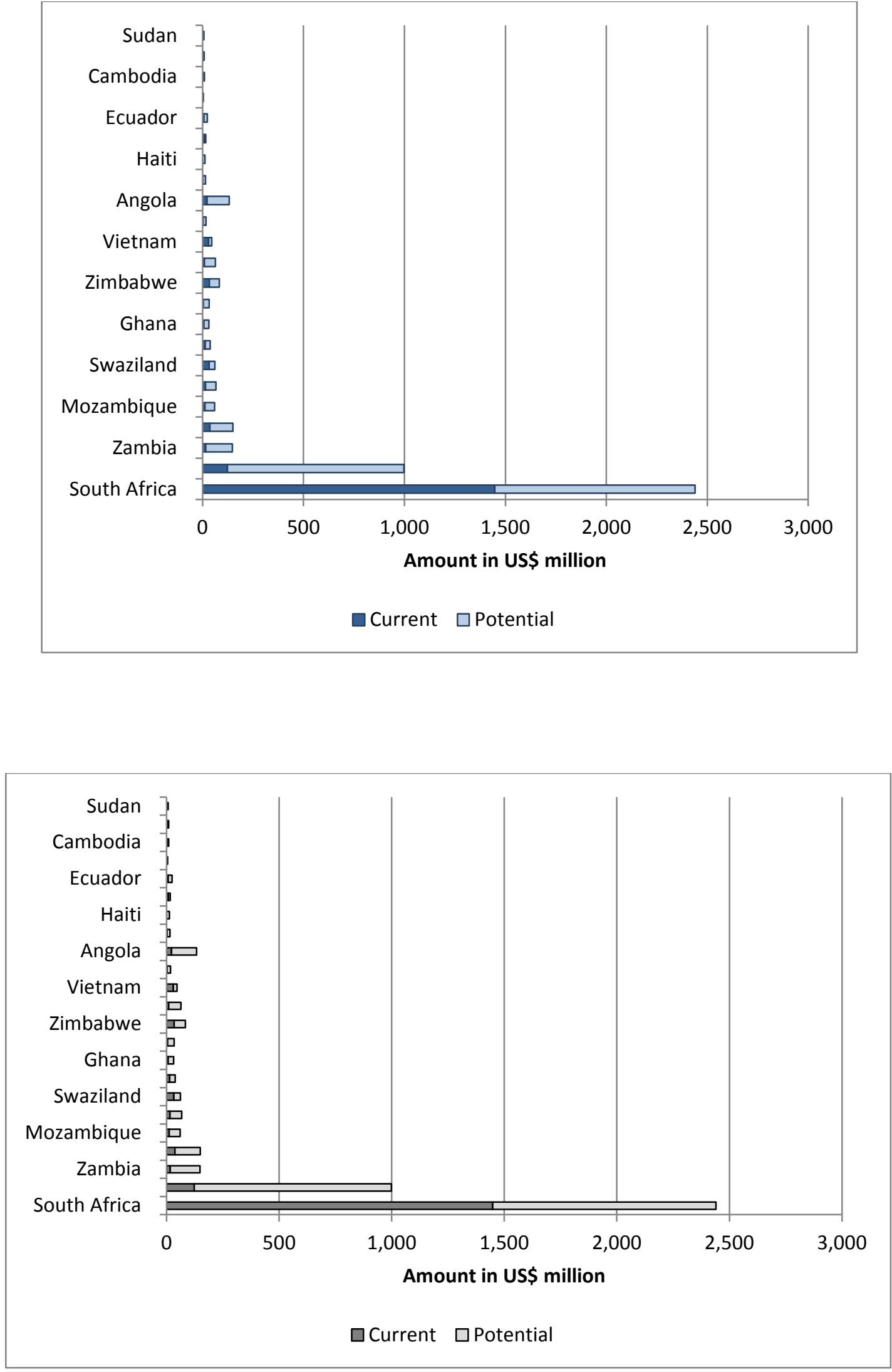

Figure 2: countries which could create fiscal space for HIV, and potential adjustment 

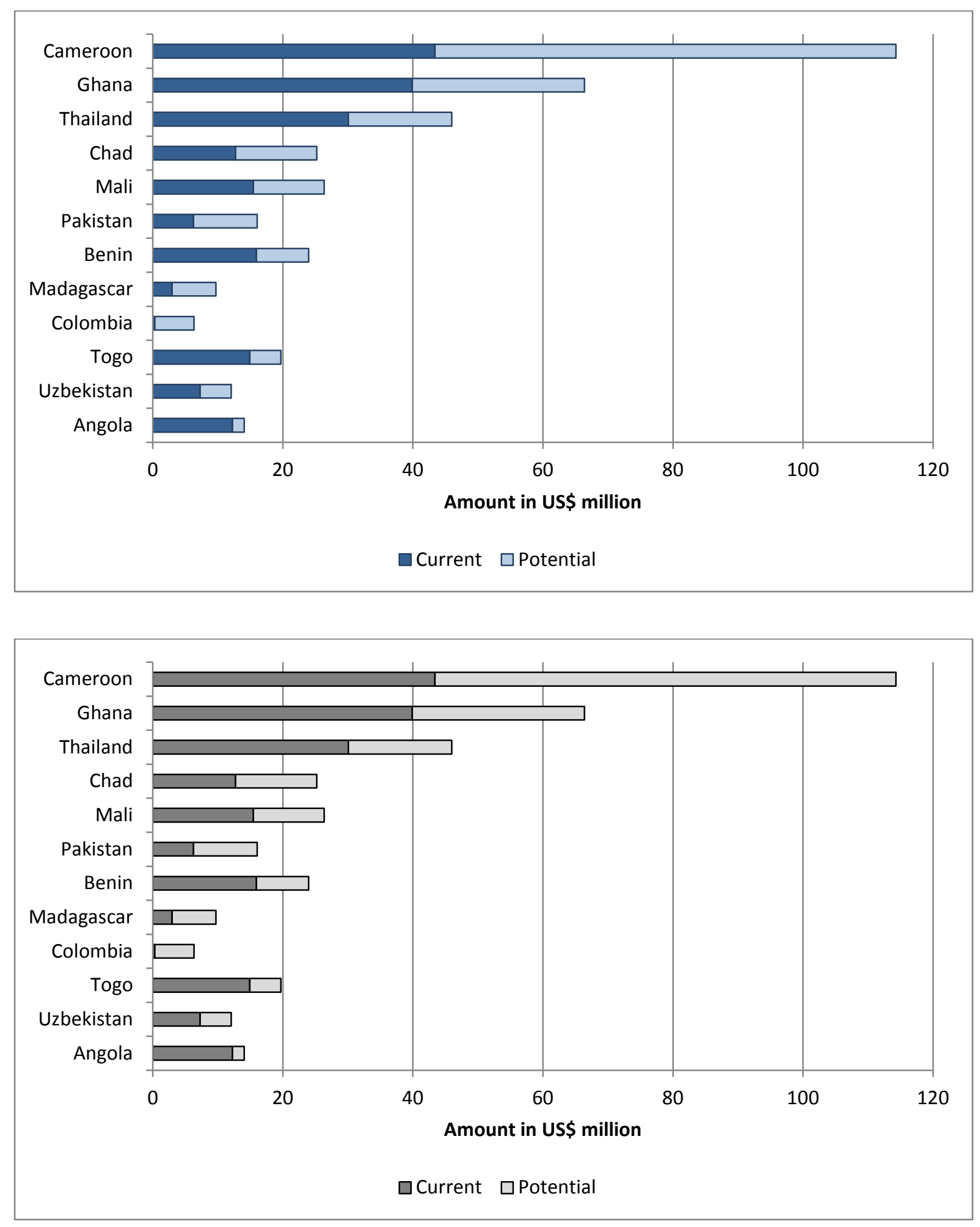

Figure 3: countries which could receive more aid for HIV, and potential adjustment 


\section{Online Appendix}

\section{A. Sample}

Countries for which data on financing for HIV, HIV prevalence, GDP per capita and governance effectiveness are available:

\begin{tabular}{|c|c|c|}
\hline Afghanistan $^{4}$ & Gambia $^{2}$ & Nepal \\
\hline Algeria & Georgia & Nicaragua \\
\hline Angola & Ghana & Niger \\
\hline Armenia & Guatemala & Nigeria \\
\hline Azerbaijan & Guinea & Pakistan \\
\hline Bangladesh & Guinea-Bissau & Panama \\
\hline Belarus & Guyana $^{3,4,5}$ & Papua New Guinea \\
\hline Belize & Haiti & Paraguay \\
\hline Benin & Honduras & Peru $^{2}$ \\
\hline Bolivia & India $^{2}$ & Philippines \\
\hline Botswana & Indonesia & Rwanda \\
\hline Brazil $^{2}$ & Iran & Sao Tome and Principe \\
\hline Burkina Faso & Jamaica & Senegal \\
\hline Burundi & Kazakhstan & Sierra Leone \\
\hline Cambodia & Kenya & South Africa \\
\hline Cameroon & Kyrgyzstan & South Sudan ${ }^{4}$ \\
\hline Cape Verde & Lao & Sri Lanka \\
\hline Central African Republic & Lebanon & Sudan \\
\hline Chad & Lesotho $^{4,5}$ & Suriname ${ }^{5}$ \\
\hline Colombia & Liberia $^{4,5}$ & Swaziland \\
\hline Congo, Dem Rep & Madagascar & Tajikistan \\
\hline Congo, Republic of & Malawi $^{4}$ & Thailand \\
\hline Costa Rica & Malaysia & Togo \\
\hline Cote d'Ivoire & Mali & Tunisia ${ }^{4,5}$ \\
\hline Djibouti & Mauritania $^{1}$ & Uganda \\
\hline Dominican Republic & Mauritius & Ukraine \\
\hline Ecuador & Mexico & Uzbekistan \\
\hline Egypt $^{4,5}$ & Moldova & Vietnam \\
\hline El Salvador & Mongolia & Yemen $^{4,5}$ \\
\hline Eritrea & Morocco & Zambia \\
\hline Ethiopia & Mozambique & Zimbabwe \\
\hline Fiji & Myanmar & \\
\hline Gabon & Namibia & \\
\hline \multicolumn{3}{|c|}{$\begin{array}{l}\text { 1. Domestic expenditures for HIV per PLHIV are equal to } 0 \text { implying that the log of the } \\
\text { variable does not exist }\end{array}$} \\
\hline \multicolumn{3}{|c|}{$\begin{array}{l}\text { 2. International expenditures for HIV per PLHIV are equal to } 0 \text { implying that the log of the } \\
\text { variable does not exist }\end{array}$} \\
\hline \multicolumn{3}{|c|}{ 3. Information on domestic financing is unavailable } \\
\hline \multicolumn{3}{|c|}{ 4. The lagged indicator of domestic financing is unavailable } \\
\hline 5. The lagged indicator of & tional financing & \\
\hline
\end{tabular}




\begin{tabular}{|c|c|c|c|c|}
\hline & $\begin{array}{c}\text { (1) } \\
\text { HIV prev. } \\
\text { (log) }\end{array}$ & $\begin{array}{c}\text { (2) } \\
\text { International exp. } \\
\text { per PLHIV (log) }\end{array}$ & $\begin{array}{c}\text { (3) } \\
\text { HIV prev. } \\
\text { (log) }\end{array}$ & $\begin{array}{c}\text { (4) } \\
\text { HIV prev. } \\
(\log )\end{array}$ \\
\hline GDP p.c. (log) & $\begin{array}{l}0.0646 \\
(0.174)\end{array}$ & $\begin{array}{c}-0.341^{* *} \\
(0.138)\end{array}$ & $\begin{array}{c}0.409 * * \\
(0.179)\end{array}$ & $\begin{array}{l}-0.103 \\
(0.184)\end{array}$ \\
\hline Governement effectiveness & $\begin{array}{c}0.132 \\
(0.282)\end{array}$ & $\begin{array}{l}-0.242 \\
(0.295)\end{array}$ & $\begin{array}{l}0.595^{*} \\
(0.315)\end{array}$ & $\begin{array}{l}0.601^{*} \\
(0.344)\end{array}$ \\
\hline $\begin{array}{l}\text { Domestic expenditures } \\
\text { per PLHIV (log, 3-year lag) }\end{array}$ & & & $\begin{array}{c}-0.396 * * * \\
(0.130)\end{array}$ & \\
\hline $\begin{array}{l}\text { Distance to the origin of the } \\
\text { HIV virus (Oster, 2012) (log) }\end{array}$ & $\begin{array}{c}-0.999 * * * \\
(0.206)\end{array}$ & $\begin{array}{c}0.496 * * * \\
(0.126)\end{array}$ & $\begin{array}{c}-1.010^{* * *} \\
(0.227)\end{array}$ & $\begin{array}{c}-1.238^{* * *} \\
(0.224)\end{array}$ \\
\hline PEPFAR focus country & $\begin{array}{c}1.454^{* * *} \\
(0.331)\end{array}$ & $\begin{array}{c}0.548^{* *} \\
(0.257)\end{array}$ & & \\
\hline Constant & $\begin{array}{c}2.427 \\
(1.941)\end{array}$ & $\begin{array}{c}3.630 * * \\
(1.575)\end{array}$ & $\begin{array}{c}2.261 \\
(1.710)\end{array}$ & $\begin{array}{c}6.145^{* * *} \\
(1.941)\end{array}$ \\
\hline Observations & 83 & 83 & 80 & 86 \\
\hline R-squared & 0.42 & 0.14 & 0.39 & 0.30 \\
\hline First stage Angrist-Pischke F-test & 72 & 15.2 & 18.51 & 28.98 \\
\hline
\end{tabular}

${ }^{*} \mathrm{p}<0.10,{ }^{* *} \mathrm{p}<0.05,{ }^{* * *} \mathrm{p}<0.01$. Robust standard errors in parentheses.

Appendix Table B.1. First-stages of IV regressions. Columns 1 and 2 of this table correspond to column 2 of table 2, column 3 of this table corresponds to column 4 of table 2, and column 4 of this table corresponds to columns 6 and 8 of table 2. 


\section{Equivalence between per PLHIV and per capita models}

The dependent variables used in the empirical analysis are expressed in per PLHIV terms. Thanks to the properties of logarithms, the results of the regressions are similar if the dependent variables are expressed in per capita terms, except for the coefficient associated with HIV prevalence (log) which becomes one unit larger. This appendix focuses on domestic expenditures for HIV per PLHIV, but this equivalence is also valid for international and total expenditures for HIV per PLHIV.

We start from equation (5):

$\log \left(\frac{\text { Domestic }}{\text { PLHIV }}\right)=\beta_{0}+\beta_{1} \log (G D P$ pc $)+\beta_{2} \log ($ HIV prev. $)+$ $\beta_{3}$ gov.effect. $+\beta_{4} \log \left(\frac{\text { International }}{\text { PLHIV }}\right)+\varepsilon$

This equation can be rewritten as follows thanks to the properties of $\log$ arithms $(\log (a / b)=\log (a)$ $\log (b))$ :

$\log \left(\frac{\text { Domestic }}{\text { Population }}\right)-\log \left(\frac{\text { PLHIV }}{\text { Population }}\right)=\beta_{0}+\beta_{1} \log (G D P$ pc $)+\beta_{2} \log ($ HIV prev. $)+$

$\beta_{3}$ gov.effect. $+\beta_{4} \log \left(\frac{\text { International }}{\text { PLHIV }}\right)+\varepsilon$

Because HIV prev. $=$ PLHIV /Population, the latter equation can be rewritten:

$\log \left(\frac{\text { Domestic }}{\text { Population }}\right)=\beta_{0}+\beta_{1} \log (G D P p c)+\left(\beta_{2}+1\right) \log ($ HIV prev. $)+$

$\beta_{3}$ gov.effect. $+\beta_{4} \log \left(\frac{\text { International }}{\text { PLHIV }}\right)+\varepsilon$

Similarly, equation (D.2) can be rewritten:

$\log \left(\frac{\text { Domestic }}{\text { Population }}\right)=\beta_{0}+\beta_{1} \log (G D P p c)+\left(\beta_{2}-\beta_{4}+1\right) \log ($ HIV prev. $)+$

$\beta_{3}$ gov.effect. $+\beta_{4} \log \left(\frac{\text { International }}{\text { Population }}\right)+\varepsilon$

This shows that results are similar if the dependent variable is expressed in per capita terms, except for the coefficient of HIV prevalence which is increased by one unit (equation D.2), or by $1-\beta_{4}$ unit if international financing is also expressed in per capita terms. This is true mathematically, but also empirically. In Table C.2. below, we estimate equation (D.2) in column 2, and equation (D.3) in column 3 , and compare the results to the estimation of equation (5) (column 1). All coefficients and standard errors are exactly the same, except for the coefficient associated with HIV prevalence (log).

This equivalence is also verified mathematically and empirically for the IV models.

The mathematical proof focuses on the instrumentation of HIV prevalence (log) by the distance to the origin of the HIV virus (log), but the equivalence is also verified for the instrumentation of international expenditures per PLHIV.

We want to estimate and compare equations (5) and (D.2) using an instrumental variable approach where HIV prevalence (log) is instrumented by the distance to the origin of the HIV virus (log). The first-stage regression is given by: 
$\log ($ HIV prev. $)=\alpha_{0}+\alpha_{1} \log ($ distance $)+\alpha_{2} \log (G D P$ pc $)+$

$\alpha_{3}$ gov.effect. $+\alpha_{4} \log \left(\frac{\text { International }}{\text { PLHIV }}\right)+v$

Denoting $\log (\widehat{H I V}$ prev. $)$ the predicted values of this first-stage regression, we have:

$$
\begin{aligned}
\log (\text { HIVprev. }) & \\
= & \widehat{\alpha_{0}}+\widehat{\alpha_{1}} \log (\text { distance })+\widehat{\alpha_{2}} \log (\text { GDP pc }) \\
& +\widehat{\alpha_{3}} \text { gov. effect. }+\widehat{\alpha_{4}} \log \left(\frac{\text { International }}{P L H I V}\right)+\hat{v}
\end{aligned}
$$

In line with the control-function interpretation of the IV regression (see e.g. Söderbom et al., 2015), we introduce predicted residuals of the first-stage regression into the second-stage regression:

$\log \left(\frac{\text { Domestic }}{\text { PLHIV }}\right)=\gamma_{0}+\gamma_{1} \log ($ GDP pc $)+\gamma_{2} \log ($ HIV prev. $)+$

$\gamma_{3}$ gov.effect. $+\gamma_{4} \log \left(\frac{\text { International }}{\text { PLHIV }}\right)+\gamma_{5} \hat{v}+\mu$

Again, because HIV prev. $=$ PLHIV / Population, the latter equation can be rewritten:

$\log \left(\frac{\text { Domestic }}{\text { Population }}\right)=\gamma_{0}+\gamma_{1} \log (G D P p c)+\left(\gamma_{2}+1\right) \log ($ HIV prev. $)+$

$\gamma_{3}$ gov.effect. $+\gamma_{4} \log \left(\frac{\text { International }}{\text { PLHIV }}\right)+\gamma_{5} \hat{v}+\mu$

We conclude that the per PLHIV and per capita IV models are mathematically similar, except for the coefficient associated with HIV prevalence (log) which is one unit higher.

Empirically, the equivalence is demonstrated in Table C.1, columns (4) to (6), where both HIV prevalence (log) and international expenditures for HIV per PLHIV or per capita (lagged and logged) are instrumented. Equation (5) is estimated in column (1) (OLS) and column (4) (IV/2SLS). Equation (D.2) is estimated in column (2) (OLS) and column (5) (IV/2SLS). Equation (D.3) is estimated in column (3) (OLS) and column (6) (IV/2SLS). 


\begin{tabular}{|c|c|c|c|c|c|c|}
\hline & \multirow[t]{2}{*}{ (1) } & $(2)$ & \multirow[t]{2}{*}{ (3) } & \multirow[t]{2}{*}{ (4) } & \multirow{2}{*}{$\begin{array}{l}\text { (5) } \\
\text { IV }\end{array}$} & \multirow[t]{2}{*}{$(6)$} \\
\hline & & OLS & & & & \\
\hline & \multicolumn{6}{|c|}{ Domestic expenditures for HIV (log) } \\
\hline & per PLHIV & per capita & per capita & per PLHIV & per capita & per capita \\
\hline GDP p.c. (log) & $\begin{array}{l}0.960 * * * \\
(0.125)\end{array}$ & $\begin{array}{c}0.960 * * * \\
(0.125)\end{array}$ & $\begin{array}{c}0.960 * * * \\
(0.125)\end{array}$ & $\begin{array}{c}0.869 * * * \\
(0.189)\end{array}$ & $\begin{array}{l}0.869 * * * \\
(0.189)\end{array}$ & $\begin{array}{c}0.869 * * * \\
(0.189)\end{array}$ \\
\hline HIV prevalence (log) & $\begin{array}{c}-0.283^{* * *} \\
(0.0674)\end{array}$ & $\begin{array}{c}0.717^{* * *} \\
(0.0674)\end{array}$ & $\begin{array}{l}0.501 * * * \\
(0.0842)\end{array}$ & $\begin{array}{c}-0.401 * * * \\
(0.124)\end{array}$ & $\begin{array}{c}0.599 * * * \\
(0.124)\end{array}$ & $\begin{array}{l}0.609^{*} \\
(0.360)\end{array}$ \\
\hline Governement effectiveness & $\begin{array}{c}0.785 * * * \\
(0.213)\end{array}$ & $\begin{array}{l}0.785 * * * \\
(0.213)\end{array}$ & $\begin{array}{c}0.785^{* * *} \\
(0.213)\end{array}$ & $\begin{array}{l}0.818 * * * \\
(0.242)\end{array}$ & $\begin{array}{c}0.818^{* * *} \\
(0.242)\end{array}$ & $\begin{array}{c}0.818^{* * *} \\
(0.242)\end{array}$ \\
\hline $\begin{array}{l}\text { International expenditures } \\
\text { per PLHIV (log, 3-year lag) }\end{array}$ & $\begin{array}{l}0.216^{* *} \\
(0.0842)\end{array}$ & $\begin{array}{l}0.216^{* *} \\
(0.0842)\end{array}$ & & $\begin{array}{l}-0.0104 \\
(0.412)\end{array}$ & $\begin{array}{l}-0.0104 \\
(0.412)\end{array}$ & \\
\hline $\begin{array}{l}\text { International expenditures } \\
\text { per capita (log, 3-year lag) }\end{array}$ & & & $\begin{array}{l}0.216 * * \\
(0.0842)\end{array}$ & & & $\begin{array}{l}-0.0104 \\
(0.412)\end{array}$ \\
\hline Constant & $\begin{array}{c}-4.628 * * * \\
(1.204)\end{array}$ & $\begin{array}{c}-4.628 * * * \\
(1.204)\end{array}$ & $\begin{array}{c}-4.628 * * * \\
(1.204)\end{array}$ & $\begin{array}{l}-3.284 \\
(3.158)\end{array}$ & $\begin{array}{l}-3.284 \\
(3.158)\end{array}$ & $\begin{array}{l}-3.284 \\
(3.158)\end{array}$ \\
\hline Observations & 88 & 88 & 88 & 83 & 83 & 83 \\
\hline R-squared & 0.72 & 0.74 & 0.74 & 0.69 & 0.72 & 0.72 \\
\hline First stage F-test (HIV prev.) & & & & 72 & 72 & 6.06 \\
\hline First stage F-test (International/PLHIV) & & & & 15.2 & 15.2 & 4.57 \\
\hline Kleibergen-Paap rk LM statistic & & & & 8.02 & 8.02 & 8.02 \\
\hline Kleibergen-Paap rk Wald F statistic & & & & 7.81 & 7.81 & 7.81 \\
\hline
\end{tabular}

${ }^{*} \mathrm{p}<0.10,{ }^{* *} \mathrm{p}<0.05, * * * \mathrm{p}<0.01$. Robust standard errors in parentheses.

Appendix Table C.1. Equivalence between per PLHIV and per capita models, for both OLS and IV regressions. Equation (5) is estimated in column (1) (OLS) and column (4) (IV/2SLS). Equation (D.2) is estimated in column (2) (OLS) and column (5) (IV/2SLS). Equation (D.3.) is estimated in column (3) (OLS) and column (6) (IV/2SLS). 
D. Robustness checks for the descriptive approach (Table 2)

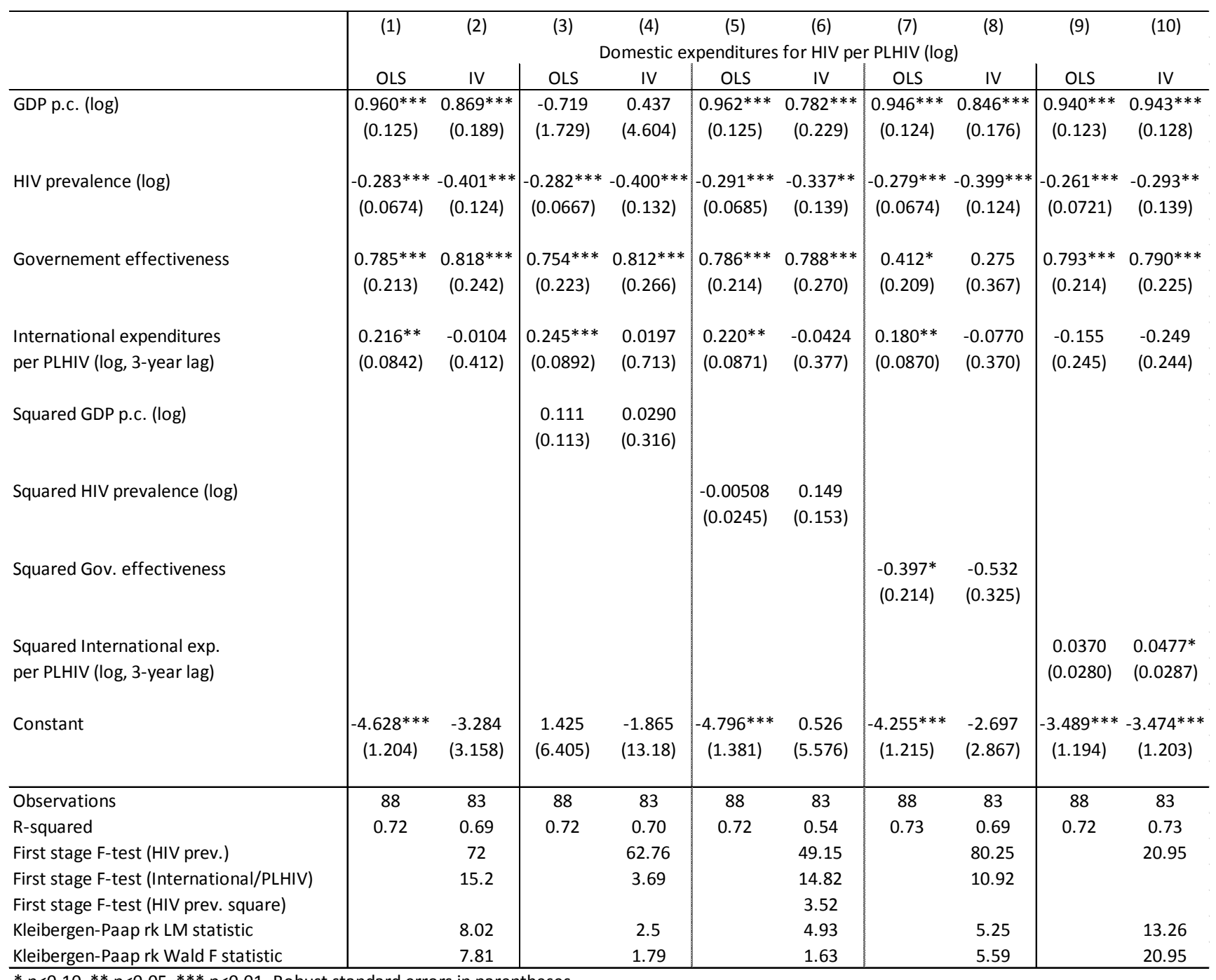

${ }^{*} p<0.10,{ }^{* *} p<0.05,{ }^{* * *} p<0.01$. Robust standard errors in parentheses.

Appendix Table D.1. Non-linear relationships for domestic expenditures for HIV per PLHIV 


\begin{tabular}{|c|c|c|c|c|c|c|c|c|c|c|}
\hline & (1) & (2) & (3) & (4) & (5) & (6) & (7) & (8) & (9) & (10) \\
\hline & \multicolumn{10}{|c|}{ International expenditures for HIV per PLHIV (log) } \\
\hline & OLS & IV & OLS & IV & OLS & IV & OLS & IV & OLS & IV \\
\hline GDP p.c. (log) & $-0.671^{* * *}$ & $-0.597 * * *$ & $3.922^{* *}$ & $3.862^{* *}$ & $-0.669 * * *$ & $-0.803 *$ & $-0.652^{* * *}$ & $-0.579 * * *$ & $-0.699 * * *$ & $-0.610^{* * *}$ \\
\hline & $(0.213)$ & $(0.220)$ & $(1.863)$ & $(1.796)$ & $(0.213)$ & (0.411) & $(0.222)$ & $(0.220)$ & $(0.213)$ & $(0.224)$ \\
\hline HIV prevalence (log) & -0.107 & $-0.312^{*}$ & -0.100 & -0.219 & -0.0686 & -0.255 & -0.106 & $-0.306 *$ & -0.0874 & $-0.313^{*}$ \\
\hline & $(0.0770)$ & $(0.169)$ & $(0.0781)$ & $(0.153)$ & $(0.0735)$ & $(0.267)$ & $(0.0773)$ & $(0.172)$ & $(0.0759)$ & $(0.167)$ \\
\hline Governement effectiveness & $\begin{array}{c}0.203 \\
(0.259)\end{array}$ & $\begin{array}{c}0.183 \\
(0.312)\end{array}$ & $\begin{array}{c}0.278 \\
(0.253)\end{array}$ & $\begin{array}{c}0.198 \\
(0.289)\end{array}$ & $\begin{array}{c}0.205 \\
(0.260)\end{array}$ & $\begin{array}{l}-0.0324 \\
(0.586)\end{array}$ & $\begin{array}{l}0.0427 \\
(0.397)\end{array}$ & $\begin{array}{l}-0.0674 \\
(0.479)\end{array}$ & $\begin{array}{c}0.213 \\
(0.257)\end{array}$ & $\begin{array}{c}0.189 \\
(0.306)\end{array}$ \\
\hline Domestic expenditures & $0.245^{* *}$ & 0.153 & $0.212^{*}$ & 0.177 & $0.234^{* *}$ & 0.580 & $0.220 *$ & 0.131 & 0.00509 & -0.00390 \\
\hline per PLHIV (log, 3-year lag) & $(0.109)$ & $(0.158)$ & $(0.107)$ & $(0.146)$ & $(0.107)$ & (0.631) & $(0.116)$ & $(0.153)$ & $(0.176)$ & $(0.167)$ \\
\hline Squared GDP p.c. (log) & & & $\begin{array}{c}-0.299 * * \\
(0.125)\end{array}$ & $\begin{array}{c}-0.292^{* *} \\
(0.120)\end{array}$ & & & & & & \\
\hline Squared HIV prevalence (log) & & & & & $\begin{array}{c}0.0258 \\
(0.0302)\end{array}$ & $\begin{array}{l}-0.312 \\
(0.391)\end{array}$ & & & & \\
\hline Squared Gov. effectiveness & & & & & & & $\begin{array}{l}-0.205 \\
(0.294)\end{array}$ & $\begin{array}{l}-0.278 \\
(0.319)\end{array}$ & & \\
\hline $\begin{array}{l}\text { Squared domestic exp. } \\
\text { per PLHIV (log, 3-year lag) }\end{array}$ & & & & & & & & & $\begin{array}{l}0.0298 \\
(0.0224)\end{array}$ & $\begin{array}{c}0.0187 \\
(0.0233)\end{array}$ \\
\hline Constant & $\begin{array}{c}9.039 * * * \\
(1.414)\end{array}$ & $\begin{array}{c}7.775^{* * *} \\
(1.589)\end{array}$ & $\begin{array}{l}-8.083 \\
(6.817)\end{array}$ & $\begin{array}{l}-8.532 \\
(6.589)\end{array}$ & $\begin{array}{c}9.749 * * * \\
(1.555)\end{array}$ & $\begin{array}{c}1.927 \\
(7.616)\end{array}$ & $\begin{array}{c}9.061^{* * *} \\
(1.411)\end{array}$ & $\begin{array}{c}7.820^{* * *} \\
(1.574)\end{array}$ & $\begin{array}{c}9.737^{* * *} \\
(1.464)\end{array}$ & $\begin{array}{c}8.132 * * * \\
(1.763)\end{array}$ \\
\hline Observations & 84 & 80 & 84 & 80 & 84 & 80 & 84 & 80 & 84 & 80 \\
\hline R-squared & 0.18 & 0.13 & 0.24 & 0.23 & 0.19 & -1.30 & 0.19 & 0.14 & 0.19 & 0.13 \\
\hline First stage F-test (HIV prev.) & & 18.51 & & 20.57 & & 15.36 & & 18.56 & & 20.95 \\
\hline First stage F-test (HIV prev. square) & & & & & & .82 & & & & \\
\hline Kleibergen-Paap rk LM statistic & & 12.19 & & 12.56 & & 1.05 & & 12.36 & & 13.13 \\
\hline Kleibergen-Paap rk Wald F statistic & & 18.51 & & 20.57 & & .33 & & 18.56 & & 20.95 \\
\hline
\end{tabular}

\section{Appendix Table D.2. Non-linear relationships for international expenditures for HIV per PLHIV}




\begin{tabular}{|c|c|c|c|c|c|c|c|c|}
\hline & (1) & (2) & (3) & (4) & (5) & (6) & (7) & (8) \\
\hline & \multicolumn{8}{|c|}{ Total expenditures for HIV per PLHIV (log) } \\
\hline & OLS & IV & OLS & IV & OLS & IV & OLS & IV \\
\hline GDP p.c. (log) & $\begin{array}{c}0.170 \\
(0.107)\end{array}$ & $\begin{array}{c}0.126 \\
(0.109)\end{array}$ & $\begin{array}{l}-0.594 \\
(1.306)\end{array}$ & $\begin{array}{l}-1.419 \\
(1.389)\end{array}$ & $\begin{array}{c}0.169 \\
(0.107)\end{array}$ & $\begin{array}{c}0.219 \\
(0.152)\end{array}$ & $\begin{array}{c}0.169 \\
(0.108)\end{array}$ & $\begin{array}{c}0.126 \\
(0.109)\end{array}$ \\
\hline HIV prevalence (log) & $\begin{array}{c}-0.243^{* * *} \\
(0.0531)\end{array}$ & $\begin{array}{c}-0.386^{* * *} \\
(0.103)\end{array}$ & $\begin{array}{c}-0.246^{* * *} \\
(0.0522)\end{array}$ & $\begin{array}{c}-0.413^{* * *} \\
(0.107)\end{array}$ & $\begin{array}{c}-0.227^{* * *} \\
(0.0521)\end{array}$ & $\begin{array}{c}-0.428^{* * *} \\
(0.136)\end{array}$ & $\begin{array}{c}-0.239 * * * \\
(0.0530)\end{array}$ & $\begin{array}{c}-0.385^{* * *} \\
(0.105)\end{array}$ \\
\hline Governement effectiveness & $\begin{array}{c}0.496 * * \\
(0.189)\end{array}$ & $\begin{array}{c}0.530 * * \\
(0.210)\end{array}$ & $\begin{array}{c}0.483^{* *} \\
(0.196)\end{array}$ & $\begin{array}{c}0.519 * * \\
(0.214)\end{array}$ & $\begin{array}{c}0.493^{* *} \\
(0.190)\end{array}$ & $\begin{array}{c}0.524 * * \\
(0.244)\end{array}$ & $\begin{array}{c}0.368 \\
(0.252)\end{array}$ & $\begin{array}{c}0.497 \\
(0.350)\end{array}$ \\
\hline Squared GDP p.c. (log) & & & $\begin{array}{c}0.0503 \\
(0.0872)\end{array}$ & $\begin{array}{c}0.101 \\
(0.0909)\end{array}$ & & & & \\
\hline Squared HIV prevalence (log) & & & & & $\begin{array}{l}0.00839 \\
(0.0199)\end{array}$ & $\begin{array}{l}-0.122^{*} \\
(0.0687)\end{array}$ & & \\
\hline Squared Gov. effectiveness & & & & & & & $\begin{array}{l}-0.134 \\
(0.180)\end{array}$ & $\begin{array}{l}-0.0327 \\
(0.253)\end{array}$ \\
\hline Constant & $\begin{array}{c}3.978^{* * *} \\
(0.843)\end{array}$ & $\begin{array}{c}3.570^{* * *} \\
(0.816)\end{array}$ & $\begin{array}{c}6.797 \\
(4.845)\end{array}$ & $\begin{array}{l}9.212 * \\
(5.104)\end{array}$ & $\begin{array}{c}4.215^{* * *} \\
(0.926)\end{array}$ & $\begin{array}{c}0.521 \\
(2.163)\end{array}$ & $\begin{array}{c}4.023^{* * *} \\
(0.840)\end{array}$ & $\begin{array}{c}3.578 * * * \\
(0.815)\end{array}$ \\
\hline Observations & 91 & 86 & 91 & 86 & 91 & 86 & 91 & 86 \\
\hline R-squared & 0.41 & 0.35 & 0.42 & 0.33 & 0.42 & 0.08 & 0.42 & 0.35 \\
\hline First stage F-test (HIV prev.) & & 28.98 & & 27.81 & & 25.52 & & 27.75 \\
\hline First stage F-test (HIV prev. square) & & & & & & 4.83 & & \\
\hline Kleibergen-Paap rk LM statistic & & 17.25 & & 15.44 & & 7.98 & & 16.93 \\
\hline Kleibergen-Paap rk Wald F statistic & & 28.98 & & 27.81 & & 2.85 & & 27.75 \\
\hline
\end{tabular}

${ }^{*} \mathrm{p}<0.10,{ }^{* *} \mathrm{p}<0.05,{ }^{* * *} \mathrm{p}<0.01$. Robust standard errors in parentheses.

\section{Appendix Table D.3. Non-linear relationships for total expenditures for HIV per PLHIV}




\begin{tabular}{|c|c|c|c|c|c|c|c|c|}
\hline & (1) & $(2)$ & (3) & (4) & (5) & (6) & (7) & (8) \\
\hline & \multicolumn{8}{|c|}{ Share of domestic expenditures in total expenditures for HIV PLHIV } \\
\hline & OLS & \begin{tabular}{l|l} 
IV &
\end{tabular} & OLS & IV & OLS & IV & OLS & IV \\
\hline GDP p.c. (log) & $\begin{array}{c}0.221 * * * \\
(0.0223)\end{array}$ & $\begin{array}{c}0.224 * * * \\
(0.0223)\end{array}$ & $\begin{array}{c}-0.808 * * * \\
(0.249)\end{array}$ & $\begin{array}{c}-0.845^{* * *} \\
(0.255)\end{array}$ & $\begin{array}{c}0.222 * * * \\
(0.0222)\end{array}$ & $\begin{array}{c}0.222^{* * *} \\
(0.0255)\end{array}$ & $\begin{array}{c}0.222 * * * \\
(0.0227)\end{array}$ & $\begin{array}{c}0.224^{* * *} \\
(0.0228)\end{array}$ \\
\hline HIV prevalence (log) & $\begin{array}{l}-0.0126 \\
(0.0106)\end{array}$ & $\begin{array}{r}-0.00171 \\
(0.0168)\end{array}$ & $\begin{array}{l}-0.0172 * \\
(0.00998)\end{array}$ & $\begin{array}{l}-0.0202 \\
(0.0162)\end{array}$ & $\begin{array}{c}-0.0199 * \\
(0.0114)\end{array}$ & $\begin{array}{c}-0.000867 \\
(0.0194)\end{array}$ & $\begin{array}{l}-0.0136 \\
(0.0106)\end{array}$ & $\begin{array}{r}-0.00351 \\
(0.0172)\end{array}$ \\
\hline Governement effectiveness & $\begin{array}{c}0.0252 \\
(0.0334)\end{array}$ & $\begin{array}{c}0.0211 \\
(0.0347)\end{array}$ & $\begin{array}{l}0.00824 \\
(0.0295)\end{array}$ & $\begin{array}{c}0.0135 \\
(0.0293)\end{array}$ & $\begin{array}{c}0.0265 \\
(0.0332)\end{array}$ & $\begin{array}{c}0.0213 \\
(0.0351)\end{array}$ & $\begin{array}{c}0.0562 \\
(0.0460)\end{array}$ & $\begin{array}{c}0.0718 \\
(0.0495)\end{array}$ \\
\hline Squared GDP p.c. (log) & & & $\begin{array}{c}0.0678 * * * \\
(0.0163)\end{array}$ & $\begin{array}{c}0.0700 * * * \\
(0.0167)\end{array}$ & & & & \\
\hline Squared HIV prevalence (log) & & & & & $\begin{array}{l}-0.00387 \\
(0.00384)\end{array}$ & $\begin{array}{l}0.00248 \\
(0.0150)\end{array}$ & & \\
\hline Squared Gov. effectiveness & & & & & & & $\begin{array}{c}0.0325 \\
(0.0304)\end{array}$ & $\begin{array}{c}0.0493 \\
(0.0334)\end{array}$ \\
\hline Constant & $\begin{array}{c}-1.354 * * * \\
(0.172)\end{array}$ & $\begin{array}{c}-1.312^{* * *} \\
(0.174)\end{array}$ & $\begin{array}{c}2.447^{* * *} \\
(0.926)\end{array}$ & $\begin{array}{c}2.592 * * * \\
(0.936)\end{array}$ & $\begin{array}{c}-1.463 * * * \\
(0.199)\end{array}$ & $\begin{array}{c}-1.250 * * * \\
(0.444)\end{array}$ & $\begin{array}{c}-1.365^{* * *} \\
(0.174)\end{array}$ & $\begin{array}{c}-1.325^{* * *} \\
(0.176)\end{array}$ \\
\hline Observations & 91 & 86 & 91 & 86 & 91 & 86 & 91 & 86 \\
\hline R-squared & 0.66 & 0.66 & 0.71 & 0.71 & 0.67 & 0.65 & 0.67 & 0.66 \\
\hline First stage F-test (HIV prev.) & & 28.98 & & 27.81 & & 25.52 & & 27.75 \\
\hline First stage F-test (HIV prev. square) & & & & & & 4.83 & & \\
\hline Kleibergen-Paap rk LM statistic & & 17.25 & & 15.44 & & 7.98 & & 16.93 \\
\hline Kleibergen-Paap rk Wald F statistic & & 28.98 & & 27.81 & & 2.85 & & 27.75 \\
\hline
\end{tabular}

${ }^{*} p<0.10,{ }^{* *} p<0.05, * * * p<0.01$. Robust standard errors in parentheses.

Appendix Table D.4. Non-linear relationships for the share of domestic expenditures in total expenditures for HIV 


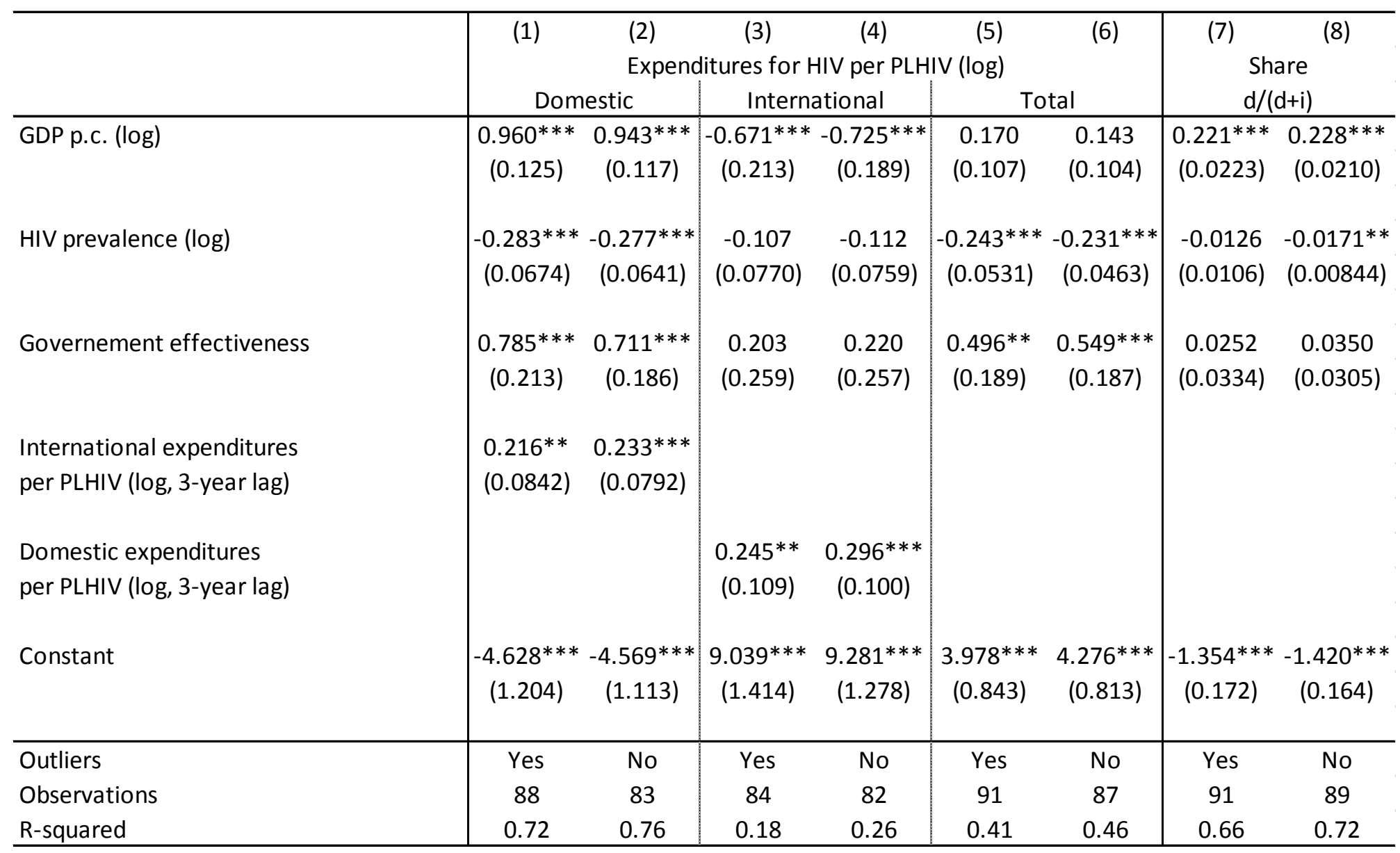

${ }^{*} p<0.10,{ }^{* *} p<0.05,{ }^{* * *} p<0.01$. Robust standard errors in parentheses.

Appendix Table D.5. Removing outliers with OLS. Observations are defined as outliers when the absolute value of their standardized residuals is above 2. 


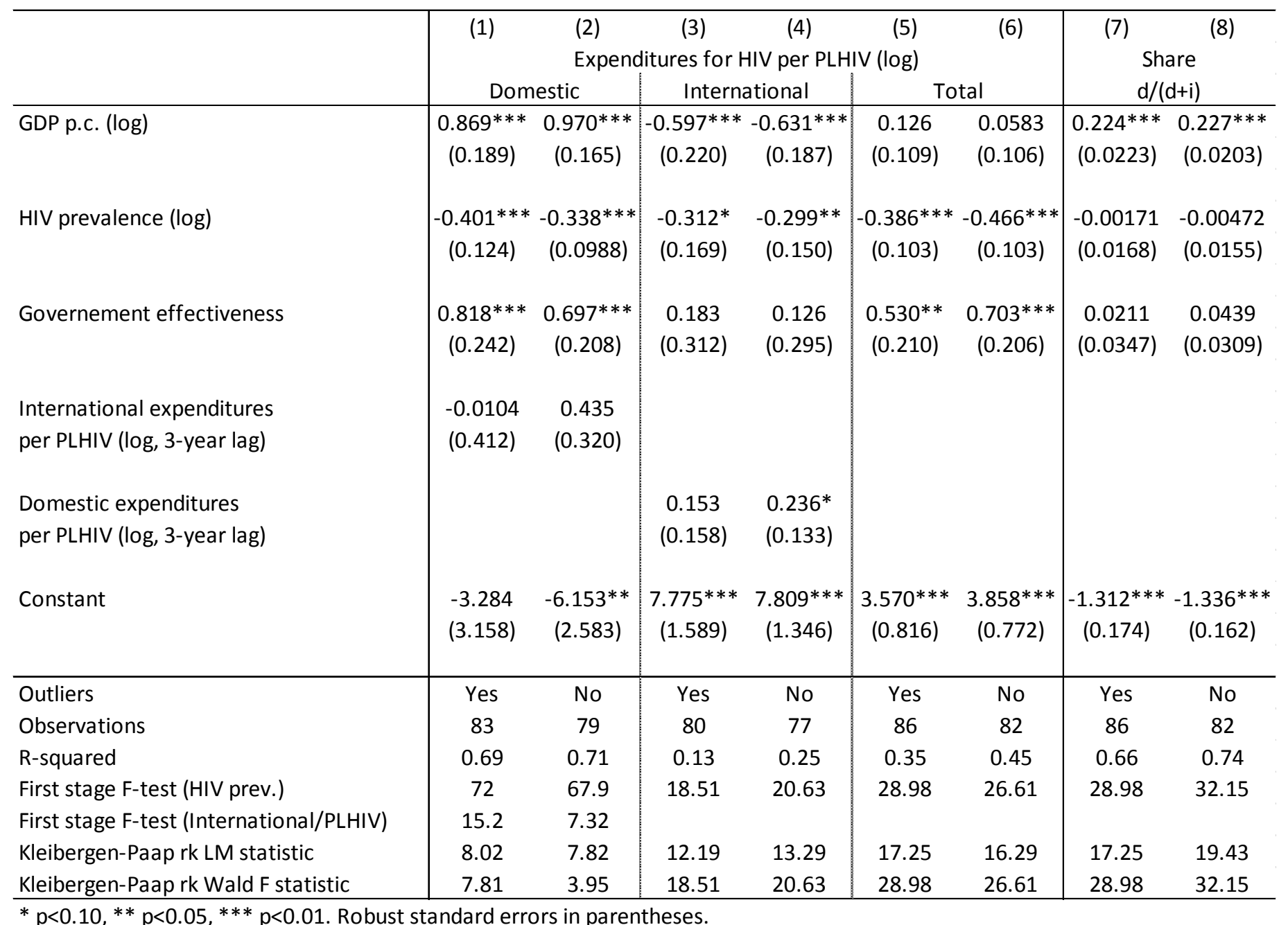

Appendix Table D.6. Removing outliers with IV regressions. Observations are defined as outliers when the absolute value of their standardized residuals is above 2. 


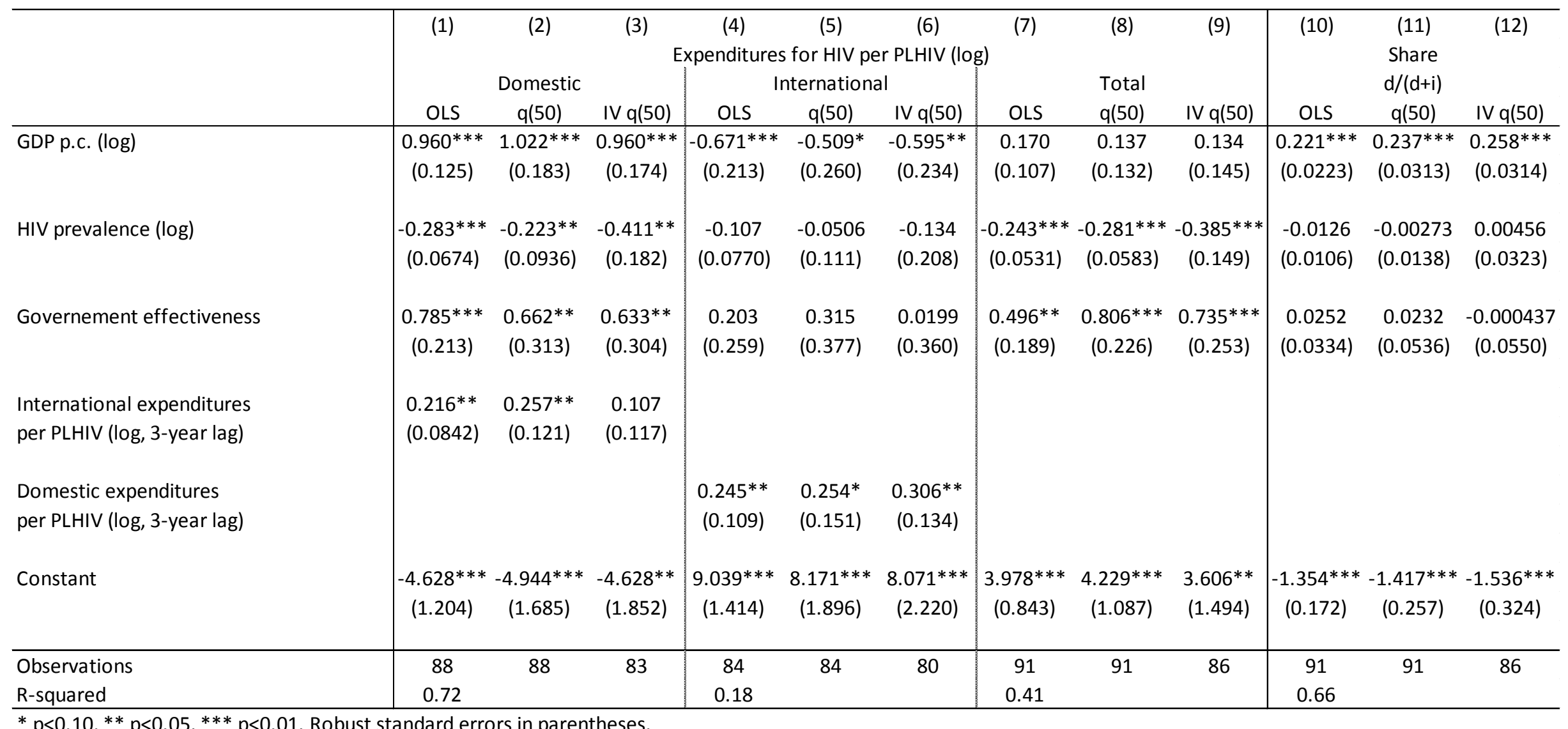

${ }^{*} \mathrm{p}<0.10,{ }^{* *} \mathrm{p}<0.05, * * * \mathrm{p}<0.01$. Robust standard errors in parentheses.

Appendix Table D.7. OLS versus quantile ( $(50)$ ) and IV quantile regressions ( $q(50))$. IV quantile regressions follow the method proposed by Chernozhukov and Hansen (2008) and implemented by Kwak (2014). 
E. Robustness checks - normative approach with domestic expenditures for HIV per PLHIV (Table 3, columns (1) to (3))

\begin{tabular}{|c|c|c|c|c|c|c|c|c|c|c|}
\hline & (1) & (2) & (3) & (4) & (5) & (6) & (7) & (8) & (9) & (10) \\
\hline & \multicolumn{10}{|c|}{ Dependent variable: domestic expenditures for HIV per PLHIV (log) } \\
\hline & \multirow[t]{2}{*}{ OLS } & \multicolumn{9}{|c|}{ Quantile regressions } \\
\hline & & $q(10)$ & $q(20)$ & $q(30)$ & $q(40)$ & $q(50)$ & $q(60)$ & $q(70)$ & $q(80)$ & $q(90)$ \\
\hline GDP p.c. (log) & $\begin{array}{c}1.188^{* * *} \\
(0.106)\end{array}$ & $\begin{array}{c}1.269 * * * \\
(0.234)\end{array}$ & $\begin{array}{c}1.308^{* * *} \\
(0.133)\end{array}$ & $\begin{array}{l}1.383^{* * *} \\
(0.147)\end{array}$ & $\begin{array}{l}1.342^{* * *} \\
(0.152)\end{array}$ & $\begin{array}{l}1.112^{* * *} \\
(0.142)\end{array}$ & $\begin{array}{l}1.050^{* * *} \\
(0.156)\end{array}$ & $\begin{array}{l}1.090^{* * *} \\
(0.136)\end{array}$ & $\begin{array}{l}1.043^{* * *} \\
(0.152)\end{array}$ & $\begin{array}{l}1.038^{* * *} \\
(0.191)\end{array}$ \\
\hline HIV prevalence (log) & $\begin{array}{c}-0.262^{* * *} \\
(0.0662)\end{array}$ & $\begin{array}{c}-0.246^{*} \\
(0.138)\end{array}$ & $\begin{array}{c}-0.274 * * * \\
(0.0782)\end{array}$ & $\begin{array}{c}-0.203^{* *} \\
(0.0868)\end{array}$ & $\begin{array}{l}-0.272 * * * \\
(0.0897)\end{array}$ & $\begin{array}{l}-0.292^{* * *} \\
(0.0837)\end{array}$ & $\begin{array}{c}{ }^{k}-0.326^{* * *} \\
(0.0920)\end{array}$ & $\begin{array}{c}-0.319 * * * \\
(0.0801)\end{array}$ & $\begin{array}{l}-0.237 * * * \\
(0.0894)\end{array}$ & $\begin{array}{l}-0.221^{*} \\
(0.112)\end{array}$ \\
\hline Constant & $\begin{array}{c}-5.599 * * * \\
(0.835)\end{array}$ & $\begin{array}{c}-7.465 * * * \\
(1.826)\end{array}$ & $\begin{array}{c}-7.518 * * * \\
(1.036)\end{array}$ & $\begin{array}{l}-7.373^{* * *} \\
(1.150)\end{array}$ & $\begin{array}{l}-7.150 * * * \\
(1.189)\end{array}$ & $\begin{array}{l}-5.137^{* * *} \\
(1.109)\end{array}$ & $\begin{array}{l}-4.602 * * * \\
(1.219)\end{array}$ & $\begin{array}{l}-4.611^{* * *} \\
(1.062)\end{array}$ & $\begin{array}{l}-3.421 * * * \\
(1.184)\end{array}$ & $\begin{array}{l}-3.054^{* *} \\
(1.487)\end{array}$ \\
\hline $\begin{array}{l}\text { Observations } \\
\text { R-squared }\end{array}$ & $\begin{array}{r}95 \\
0.636 \\
\end{array}$ & 95 & 95 & 95 & 95 & 95 & 95 & 95 & 95 & 95 \\
\hline
\end{tabular}

Appendix Table A.9. Quantile regressions 


\begin{tabular}{|c|c|c|c|c|c|c|c|c|c|}
\hline & (1) & $(2)$ & (3) & (4) & (5) & (6) & (7) & (8) & (9) \\
\hline & \multicolumn{9}{|c|}{ Domestic expenditures for HIV per PLHIV (log) } \\
\hline & \multirow{2}{*}{\multicolumn{3}{|c|}{ OLS }} & \multicolumn{5}{|c|}{ Quantile regressions } & \multirow[b]{2}{*}{$q(75)$} \\
\hline & & & & $q(50)$ & $q(50)$ & $q(50)$ & $q(75)$ & $q(75)$ & \\
\hline \multirow[t]{2}{*}{ GDP p.c. (log) } & $1.188 * * *$ & 0.482 & $1.187^{* * *}$ & $1.112^{* * *}$ & -0.570 & $1.108 * * *$ & $1.096 * * *$ & 1.399 & $1.097 * * *$ \\
\hline & $(0.106)$ & (1.658) & $(0.105)$ & $(0.142)$ & $(2.328)$ & $(0.145)$ & $(0.133)$ & $(2.433)$ & $(0.144)$ \\
\hline \multirow[t]{2}{*}{ HIV prevalence (log) } & $-0.262 * * *$ & $-0.266 * * *$ & $-0.254 * * *$ & $-0.292 * * *$ & $-0.307 * * *$ & $-0.290 * * *$ & $-0.218 * * *$ & $-0.221 * *$ & $-0.215^{* *}$ \\
\hline & $(0.0662)$ & $(0.0664)$ & $(0.0724)$ & $(0.0837)$ & $(0.0840)$ & $(0.107)$ & $(0.0781)$ & $(0.0878)$ & $(0.106)$ \\
\hline \multirow[t]{2}{*}{ Squared GDP p.c. (log) } & & 0.0461 & & & 0.108 & & & -0.0196 & \\
\hline & & $(0.106)$ & & & $(0.152)$ & & & (0.159) & \\
\hline \multirow[t]{2}{*}{ Squared HIV prevalence (log) } & & & 0.00464 & & & 0.0172 & & & 0.0162 \\
\hline & & & $(0.0258)$ & & & $(0.0349)$ & & & $(0.0347)$ \\
\hline Constant & $\begin{array}{c}-5.599 * * * \\
(0.835)\end{array}$ & $\begin{array}{l}-2.967 \\
(6.347)\end{array}$ & $\begin{array}{c}-5.465 * * * \\
(0.945)\end{array}$ & $\begin{array}{l}-5.137^{* * *} \\
(1.109)\end{array}$ & $\begin{array}{l}1.250 \\
(8.733)\end{array}$ & $\begin{array}{l}-4.744^{* * *} \\
(1.513)\end{array}$ & $\begin{array}{l}-3.866^{* * *} \\
(1.035)\end{array}$ & $\begin{array}{l}-5.046 \\
(9.127)\end{array}$ & $\begin{array}{l}-3.547^{* *} \\
(1.505)\end{array}$ \\
\hline Observations & 95 & 95 & 95 & 95 & 95 & 95 & 95 & 95 & 95 \\
\hline R-squared & 0.636 & 0.637 & 0.636 & & & & & & \\
\hline
\end{tabular}

${ }^{*} \mathrm{p}<0.10,{ }^{* *} \mathrm{p}<0.05,{ }^{* * *} \mathrm{p}<0.01$. Standard errors in parentheses (robust standard errors in Columns (1) to (3))

Appendix Table A.10. Non-linear relationships with variables of interest 


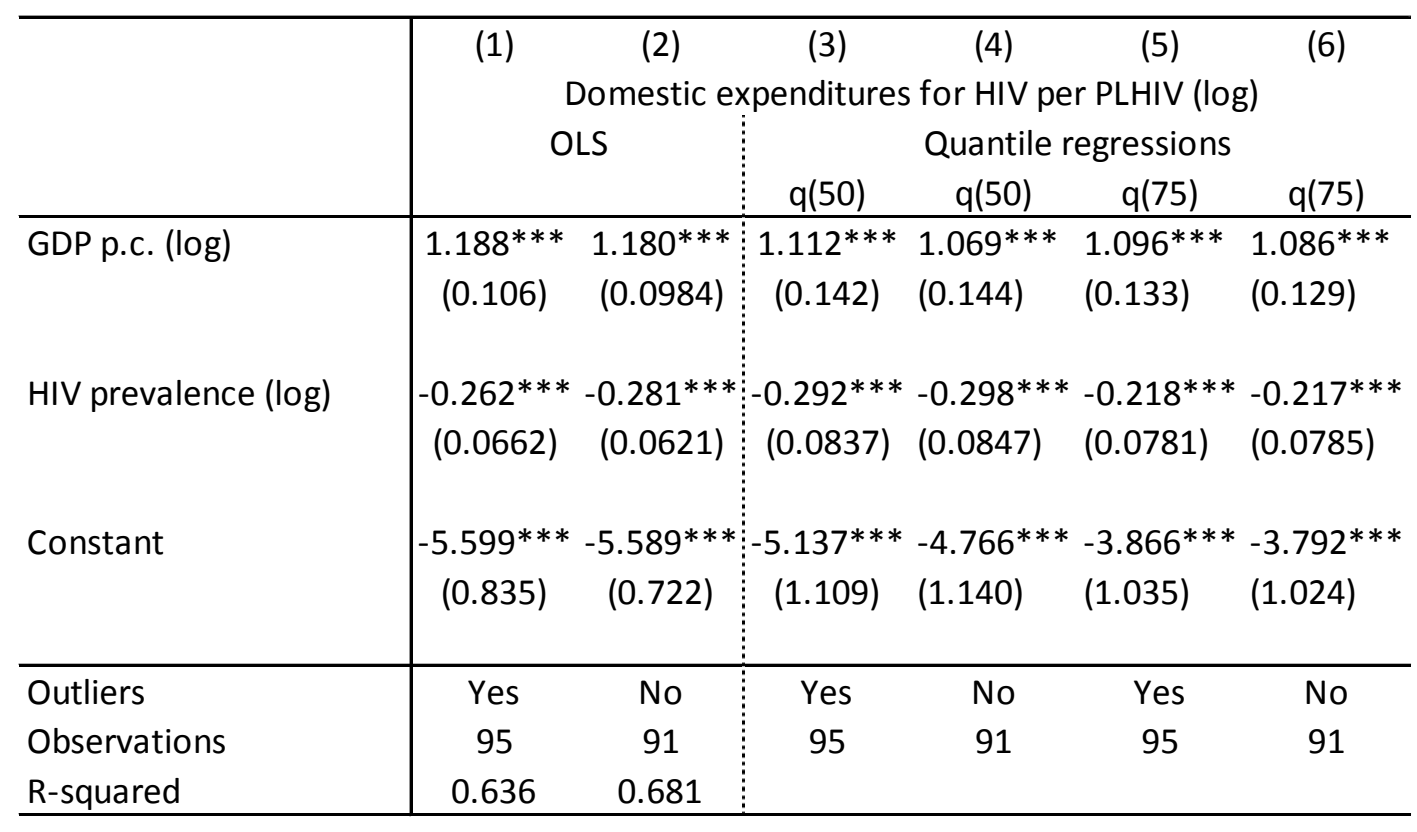

$* \mathrm{p}<0.10, * * \mathrm{p}<0.05, * * * \mathrm{p}<0.01$. Standard errors in parentheses (robust standard errors in

Columns (1) and (2))

Appendix Table A.11. Without outliers. Observations are defined as outliers when the absolute value their standardized residuals is above 2. 


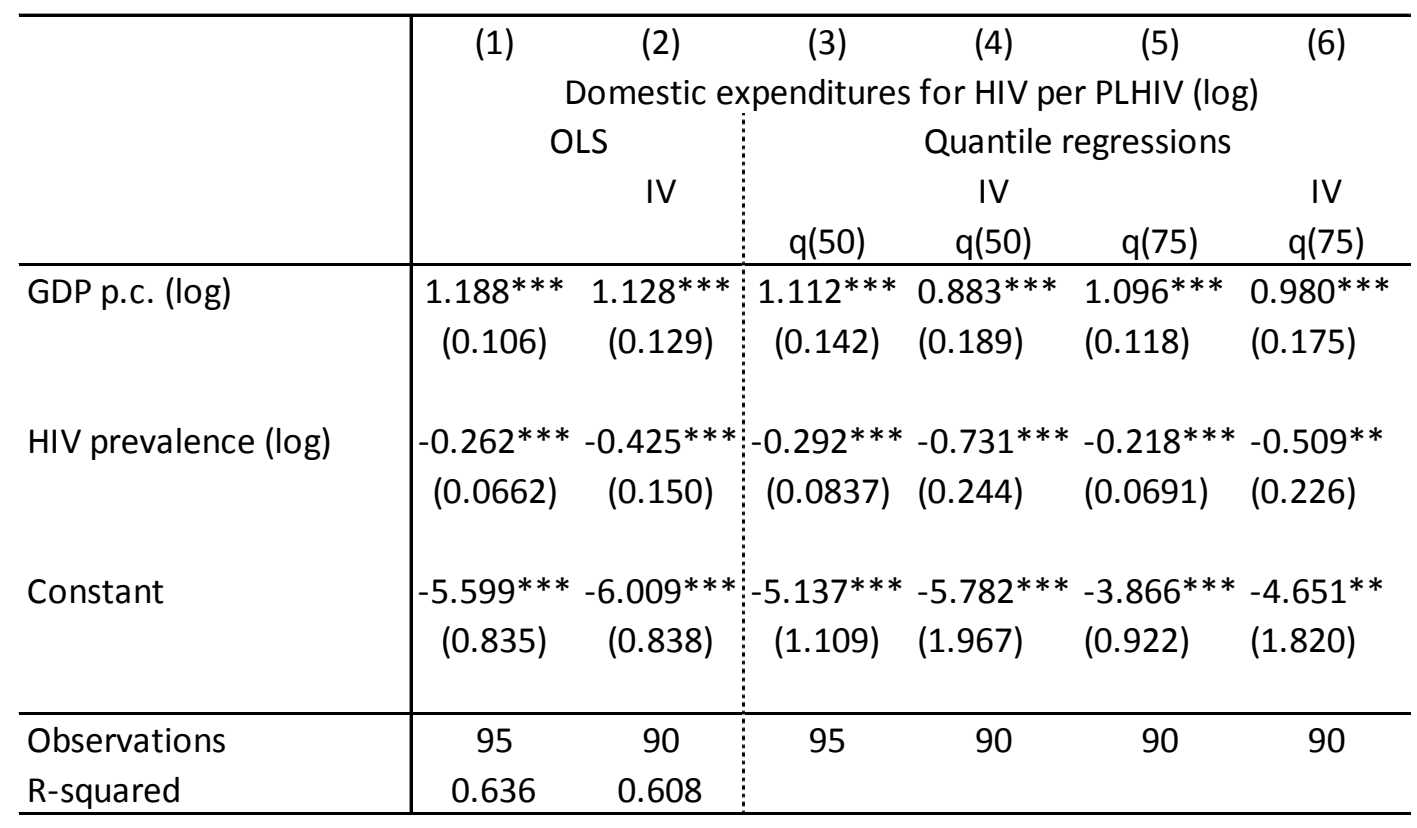

$* \mathrm{p}<0.10, * * \mathrm{p}<0.05, * * * \mathrm{p}<0.01$. Standard errors in parentheses (robust standard errors in Columns (1) and (2))

Appendix Table A.12. IV Quantile regressions, following the method proposed by Chernozhukov and Hansen (2008) and implemented by Kwak (2014). 
To obtain column (6):

- We take the exponential of the predicted values of the regression presented in Table 3, column (3), and multiply the result by the number of people living with HIV. From this value, we subtract public expenditures on HIV (column 3) to obtain the "potential" of countries.

- We take the difference between the cost of UNAIDS fast-track (column 5) and public expenditures on HIV (column 4) to obtain the "gap" between domestic expenditures and financing needs.

- Column (6) is the minimum between the "potential" and the "gap".

To obtain column (7):

- We take the difference between international expenditures on HIV (column 4) and the "gap". Negative differences are replaced by 0.

- To obtain the amound of aid that could be reallocated, we take the minimum between this difference, international expenditures on HIV (column 4) and the measure of fiscal space that can be created (column 6).

To obtain columns (9) and (10), we repeat the procedure except that we only consider the cost of ART and testing from UNAIDS fast-track estimates. Totals discussed in the main text are presented in the last row.

(3)

(4)

\section{(7)}

$(8)$

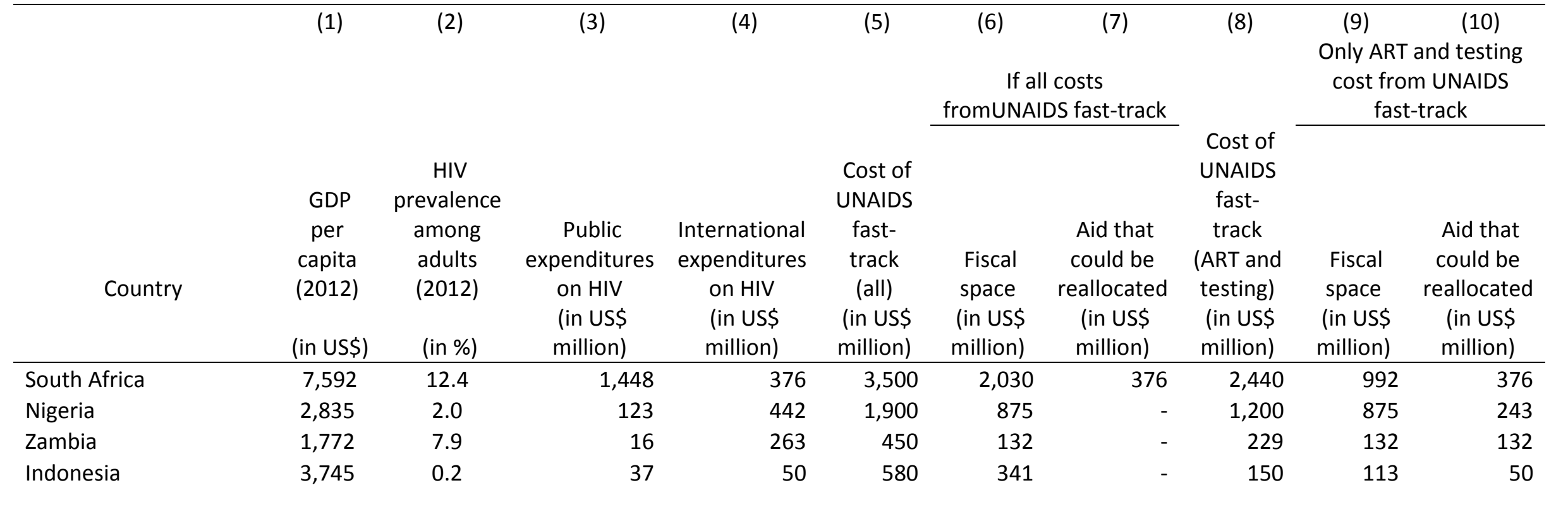




$\begin{array}{lcc}\text { Mozambique } & 590 & 5.6 \\ \text { Cameroon } & 1,234 & 2.8 \\ \text { Swaziland } & 4,551 & 18.3 \\ \text { Cote d'Ivoire } & 1,235 & 2.2 \\ \text { Ghana } & 1,683 & 1.1 \\ \text { Myanmar } & 1,100 & 0.5 \\ \text { Zimbabwe } & 961 & 10.0 \\ \text { Dominican Republic } & 6,252 & 0.8 \\ \text { Vietnam } & 1,753 & 0.3 \\ \text { Congo, Dem Rep } & 369 & 0.6 \\ \text { Angola } & 5,018 & 1.2 \\ \text { South Sudan } & 1,085 & 1.6 \\ \text { Haiti } & 775 & 1.6 \\ \text { Congo, Republic of } & 3,343 & 2.0 \\ \text { Ecuador } & 5,645 & 0.2 \\ \text { Nepal } & 686 & 0.2 \\ \text { Cambodia } & 946 & 0.5 \\ \text { Philippines } & 2,611 & 0.0 \\ \text { Sudan } & 1,787 & 0.1 \\ \text { Sierra Leone } & 634 & 0.9 \\ \text { Panama } & 9,489 & 0.4 \\ \text { Senegal } & 1,037 & 0.4 \\ \text { Pakistan } & 1,258 & 0.0 \\ \text { Central African Republic } & 480 & 2.8 \\ \text { Jamaica } & 5,325 & 1.0 \\ \text { Moldova } & 2,046 & 0.5 \\ \text { Bolivia } & 2,509 & 0.2 \\ \text { Tunisia } & 4,198 & 0.0 \\ \text { Togo } & 590 & 1.7 \\ \text { Suriname } & 9,194 & 0.7 \\ \text { Djibouti } & 1,523 & 1.1 \\ & & \\ & & \\ & & \end{array}$

12
15
33
14
7
4
34
9
30
3
22
2
0
9
6
0
5
4
4
0
19
3
4
2
4
2
5
0
2
2
0

$\begin{array}{rrr}329 & 650 & 49 \\ 43 & 190 & 52 \\ 63 & 110 & 29 \\ 90 & 140 & 42 \\ 40 & 92 & 47 \\ 47 & 130 & 29 \\ 216 & 500 & 50 \\ 21 & 120 & 56 \\ 65 & 130 & 36 \\ 140 & 360 & 15 \\ 12 & 260 & 153 \\ 22 & 92 & 16 \\ 126 & 130 & 12 \\ 9 & 38 & 21 \\ 6 & 58 & 24 \\ 21 & 26 & 4 \\ 45 & 27 & 4 \\ 6 & 110 & 13 \\ 9 & 30 & 12 \\ 21 & 31 & 3 \\ 3 & 39 & 5 \\ 20 & 26 & 4 \\ 6 & 280 & 16 \\ 14 & 34 & 3 \\ 11 & 27 & 16 \\ 7 & 28 & 3 \\ 5 & 32 & 3 \\ 3 & 9 & 2 \\ 15 & 43 & 4 \\ 2 & 8 & 3 \\ 3 & 6 & 1\end{array}$

$\begin{array}{rrrr}- & 207 & 49 & 49 \\ - & 79 & 52 & 31 \\ 11 & 69 & 29 & 29 \\ 10 & 38 & 25 & 25 \\ 1 & 31 & 24 & 24 \\ - & 58 & 29 & 23 \\ - & 279 & 50 & 21 \\ - & 64 & 54 & 21 \\ 0 & 46 & 16 & 16 \\ - & 120 & 15 & 15 \\ - & 133 & 111 & 12 \\ - & 14 & 12 & 12 \\ 4 & 46 & 12 & 12 \\ 0 & 16 & 7 & 7 \\ - & 24 & 17 & 6 \\ - & 7 & 4 & 4 \\ 4 & 9 & 4 & 4 \\ - & 9 & 4 & 4 \\ - & 7 & 4 & 4 \\ - & 8 & 3 & 3 \\ - & 23 & 4 & 3 \\ 1 & 6 & 3 & 3 \\ - & 7 & 3 & 3 \\ - & 15 & 3 & 3 \\ 4 & 7 & 3 & 3 \\ - & 9 & 3 & 2 \\ - & 7 & 2 & 2 \\ - & 2 & 2 & 2 \\ - & 19 & 4 & 2 \\ 0 & 4 & 2 & 2 \\ - & 3 & 1 & 1\end{array}$




$\begin{array}{lcc}\text { Liberia } & 439 & 0.8 \\ \text { Belize } & 4,618 & 1.0 \\ \text { Yemen } & 1,368 & 0.0 \\ \text { Uzbekistan } & 1,721 & 0.1 \\ \text { Lao } & 1,414 & 0.2 \\ \text { Morocco } & 3,022 & 0.1 \\ \text { Sri Lanka } & 2,874 & 0.0 \\ \text { Afghanistan } & 681 & 0.0 \\ \text { Gabon } & 11,153 & 3.0 \\ \text { Colombia } & 7,934 & 0.3 \\ \text { Burkina Faso } & 679 & 0.6 \\ \text { Egypt } & 3,183 & 0.0 \\ \text { Mexico } & 10,137 & 0.2 \\ \text { Bangladesh } & 916 & 0.0 \\ \text { Malaysia } & 10,653 & 0.3 \\ \text { Belarus } & 6,721 & 0.3 \\ \text { Ethiopia } & 504 & 0.9 \\ \text { Papua New Guinea } & 2,148 & 0.5 \\ \text { Uganda } & 678 & 3.6 \\ \text { Paraguay } & 3,737 & 0.3 \\ \text { Mauritius } & 8,932 & 0.7 \\ \text { Mongolia } & 4,329 & 0.0 \\ \text { Chad } & 1,152 & 1.6 \\ \text { Madagascar } & 445 & 0.2 \\ \text { Costa Rica } & 9,737 & 0.2 \\ \text { Tajikistan } & 953 & 0.2 \\ \text { Namibia } & 6,068 & 9.3 \\ \text { Armenia } & 3,576 & 0.1 \\ \text { Burundi } & 286 & 1.0 \\ \text { Nicaragua } & 505 & 0.2 \\ \text { Eritrea } & & 0.2 \\ & \end{array}$

0
1
0
11
1
10
1
0
5
83
8
4
494
3
48
15
56
6
41
11
5
2
5
3
18
3
135
2
0
10
1

$\begin{array}{rrrrrrr}32 & 12 & 1 & 1 & 3 & 1 & 1 \\ 2 & 5 & 1 & - & 2 & 1 & 1 \\ 1 & 15 & 2 & - & 2 & 1 & 1 \\ 7 & 61 & 2 & - & 12 & 1 & 1 \\ 11 & 10 & 2 & 2 & 2 & 1 & 1 \\ 10 & 29 & 6 & - & 11 & 1 & 1 \\ 1 & 11 & 2 & - & 2 & 1 & 1 \\ 4 & 30 & 1 & - & 1 & 1 & 1 \\ 0 & 64 & 53 & - & 39 & 34 & 0 \\ 0 & 260 & 95 & - & 133 & 50 & 0 \\ 41 & 61 & 0 & - & 20 & 0 & 0 \\ 4 & 45 & 5 & - & 4 & 0 & 0 \\ 12 & 910 & - & - & 569 & - & - \\ 16 & 39 & 0 & - & 2 & - & - \\ 2 & 80 & 32 & 2 & 26 & - & - \\ 6 & 39 & 15 & - & 9 & - & - \\ 356 & 370 & - & - & 209 & - & - \\ 30 & 14 & 4 & 4 & 5 & - & - \\ 275 & 730 & 31 & - & 420 & 31 & - \\ 3 & 28 & - & - & 13 & - & - \\ 2 & 20 & 6 & - & 4 & - & - \\ 1 & 6 & - & - & 0 & - & - \\ 13 & 110 & 16 & - & 59 & 16 & - \\ 3 & 52 & 0 & - & 2 & - & - \\ 2 & 27 & - & - & 14 & - & - \\ 10 & 19 & - & - & 2 & - & - \\ 73 & 220 & - & - & 104 & - & - \\ 5 & 9 & 1 & - & 1 & - & - \\ 16 & 55 & 2 & - & 28 & 2 & - \\ 15 & 10 & - & - & 1 & - & - \\ 13 & 16 & - & - & 4 & - & -\end{array}$




\begin{tabular}{|c|c|c|c|c|c|c|c|c|c|c|}
\hline Mali & 703 & 0.8 & 6 & 15 & 78 & 3 & - & 37 & 3 & - \\
\hline India & 1,477 & 0.2 & 159 & - & 710 & 376 & - & 415 & 255 & - \\
\hline Azerbaijan & 7,472 & 0.1 & 14 & 6 & 31 & 0 & - & 4 & - & - \\
\hline Malawi & 360 & 5.8 & 12 & 134 & 440 & 12 & - & 174 & 12 & - \\
\hline Benin & 751 & 0.7 & 4 & 16 & 72 & 2 & - & 28 & 2 & - \\
\hline Niger & 435 & 0.3 & 5 & 11 & 35 & - & - & 6 & - & - \\
\hline Thailand & 5,849 & 0.7 & 253 & 30 & 330 & 77 & 30 & 220 & - & - \\
\hline Ukraine & 3,883 & 0.5 & 72 & 42 & 170 & 51 & - & 52 & - & - \\
\hline Algeria & 5,574 & 0.0 & 16 & 0 & 27 & - & - & 5 & - & - \\
\hline Fiji & 4,401 & 0.1 & 0 & 0 & 1 & 0 & - & 0 & - & - \\
\hline Mauritania & 1,401 & 0.4 & - & 3 & 14 & 3 & - & 6 & 3 & - \\
\hline Georgia & 4,131 & 0.2 & 8 & 7 & 22 & - & - & 5 & - & - \\
\hline Rwanda & 688 & 1.8 & 20 & 224 & 130 & - & - & 57 & - & - \\
\hline Botswana & 7,206 & 16.1 & 305 & 93 & 660 & - & - & 450 & - & - \\
\hline Guinea-Bissau & 600 & 2.5 & 3 & 5 & 12 & - & - & 5 & - & - \\
\hline Kazakhstan & 12,034 & 0.1 & 39 & 2 & 74 & 6 & - & 18 & - & - \\
\hline Honduras & 2,333 & 0.3 & 16 & 17 & 32 & - & - & 12 & - & - \\
\hline Brazil & 12,106 & 0.4 & 780 & - & 1,300 & 504 & - & 670 & - & - \\
\hline Kenya & 1,239 & 3.5 & 151 & 576 & 420 & - & - & 239 & - & - \\
\hline Kyrgyzstan & 1,166 & 0.1 & 4 & 9 & 15 & - & - & 3 & - & - \\
\hline Guinea & 492 & 1.0 & 3 & 10 & 63 & 2 & - & 23 & 2 & - \\
\hline El Salvador & 3,780 & 0.3 & 44 & 14 & 33 & - & - & 17 & - & - \\
\hline Lebanon & 9,966 & 0.0 & 3 & 2 & 10 & 2 & - & 2 & - & - \\
\hline Gambia & 499 & 1.1 & 4 & - & 10 & - & - & 4 & - & - \\
\hline Total & & & 4,785 & 4,735 & 18,231 & 5,422 & 452 & 9,541 & 3,083 & 1,159 \\
\hline
\end{tabular}

Appendix Table A.13. Results from the normative approach with domestic expenditures per PLHIV 
G. Robustness checks - normative approach with international expenditures for HIV per PLHIV (Table 3, columns (4) to (6))

\begin{tabular}{|c|c|c|c|c|c|c|c|c|c|c|}
\hline & (1) & (2) & (3) & (4) & (5) & (6) & (7) & (8) & (9) & (10) \\
\hline & \multicolumn{10}{|c|}{ Dependent variable: international expenditures for HIV per PLHIV (log) } \\
\hline & \multirow[t]{2}{*}{ OLS } & \multicolumn{9}{|c|}{ Quantile regressions } \\
\hline & & $q(10)$ & $q(20)$ & $q(30)$ & $q(40)$ & $q(50)$ & $q(60)$ & $q(70)$ & $q(80)$ & $q(90)$ \\
\hline \multirow[t]{2}{*}{ GDP p.c. (log) } & $-0.671 * * *$ & -0.742 & $-0.697 * *$ & $-0.693 * *$ & $-0.530 * *$ & $-0.509 *$ & $-0.556 * *$ & $-0.563 * *$ & $-0.581^{* *}$ & -0.120 \\
\hline & $(0.213)$ & $(0.661)$ & $(0.315)$ & $(0.263)$ & $(0.261)$ & $(0.260)$ & $(0.218)$ & $(0.222)$ & $(0.225)$ & $(0.188)$ \\
\hline \multirow[t]{2}{*}{ HIV prevalence (log) } & -0.107 & 0.0284 & -0.0984 & -0.0222 & -0.0354 & -0.0506 & -0.123 & $-0.222 * *$ & $-0.203 * *$ & $-0.267 * * *$ \\
\hline & $(0.0770)$ & $(0.283)$ & $(0.134)$ & $(0.113)$ & $(0.111)$ & $(0.111)$ & $(0.0932)$ & $(0.0949)$ & $(0.0960)$ & $(0.0802)$ \\
\hline \multirow[t]{2}{*}{ Governement effectiveness } & 0.203 & 0.241 & 0.556 & $0.650^{*}$ & 0.310 & 0.315 & 0.359 & 0.194 & 0.126 & -0.255 \\
\hline & $(0.259)$ & $(0.957)$ & $(0.455)$ & $(0.381)$ & $(0.377)$ & $(0.377)$ & $(0.315)$ & $(0.321)$ & $(0.325)$ & $(0.271)$ \\
\hline Domestic expenditures & $0.245^{* *}$ & 0.256 & 0.103 & 0.190 & 0.232 & $0.254^{*}$ & $0.262^{* *}$ & $0.334 * *$ & $0.316^{* *}$ & $0.216^{*}$ \\
\hline per PLHIV (log, 3-year lag) & $(0.109)$ & $(0.383)$ & $(0.182)$ & $(0.153)$ & $(0.151)$ & $(0.151)$ & $(0.126)$ & $(0.129)$ & $(0.130)$ & (0.109) \\
\hline Constant & $\begin{array}{c}9.039 * * * \\
(1.414)\end{array}$ & $\begin{array}{l}9.131 * \\
(4.817)\end{array}$ & $\begin{array}{c}9.306 * * * \\
(2.291)\end{array}$ & $\begin{array}{l}9.699 * * * \\
(1.918)\end{array}$ & $\begin{array}{l}8.397^{* * *} \\
(1.898)\end{array}$ & $\begin{array}{l}8.171^{* * *} \\
(1.896)\end{array}$ & $\begin{array}{l}8.469 * * * \\
(1.588)\end{array}$ & $\begin{array}{l}7.840 * * * \\
(1.617)\end{array}$ & $\begin{array}{l}8.290 * * * \\
(1.636)\end{array}$ & $\begin{array}{l}4.907^{* * *} \\
(1.366)\end{array}$ \\
\hline Observations & 84 & 84 & 84 & 84 & 84 & 84 & 84 & 84 & 84 & 84 \\
\hline R-squared & 0.181 & & & & & & & & & \\
\hline
\end{tabular}

$* \mathrm{p}<0.10, * * \mathrm{p}<0.05, * * * \mathrm{p}<0.01$. Standard errors in parentheses (robust standard errors in Columns (1) and (2))

Appendix Table A.14. Quantile regressions 


\begin{tabular}{|c|c|c|c|c|c|c|c|c|c|c|c|c|}
\hline & $(1)$ & $(2)$ & (3) & (4) & (5) & (6) & (7) & (8) & (9) & $(10)$ & $(11)$ & $(12)$ \\
\hline & \multicolumn{11}{|c|}{ Domestic expenditures for HIV per PLHIV (log) } & \multirow[b]{3}{*}{$\mathrm{q}(75)$} \\
\hline & \multirow{2}{*}{\multicolumn{4}{|c|}{ OLS }} & \multicolumn{7}{|c|}{ Quantile regressions } & \\
\hline & & & & & $q(50)$ & $q(50)$ & $\mathrm{q}(50)$ & $q(50)$ & $q(75)$ & $q(75)$ & $q(75)$ & \\
\hline \multirow[t]{2}{*}{ GDP p.c. (log) } & $3.922 * *$ & $-0.669 * * *$ & $-0.652 * * *$ & ${ }^{*}-0.699 * * *$ & 2.686 & $-0.544 * *$ & $-0.540^{*}$ & $-0.561 * *$ & $7.282^{* * *}$ & $-0.730 * *$ & $-0.517^{* *}$ & $-0.648 * *$ \\
\hline & $(1.863)$ & $(0.213)$ & $(0.222)$ & $(0.213)$ & $(2.812)$ & $(0.259)$ & $(0.274)$ & $(0.274)$ & $(2.531)$ & $(0.334)$ & $(0.254)$ & $(0.286)$ \\
\hline \multirow[t]{2}{*}{ HIV prevalence (log) } & -0.100 & -0.0686 & -0.106 & -0.0874 & -0.0451 & -0.0548 & -0.0323 & -0.0403 & 0.0331 & -0.123 & -0.00370 & -0.0683 \\
\hline & $(0.0781)$ & $(0.0735)$ & $(0.0773)$ & $(0.0759)$ & $(0.114)$ & $(0.127)$ & $(0.116)$ & $(0.119)$ & $(0.102)$ & $(0.163)$ & $(0.108)$ & $(0.124)$ \\
\hline \multirow[t]{2}{*}{ Governement effectiveness } & 0.278 & 0.205 & 0.0427 & 0.213 & 0.569 & 0.135 & 0.379 & 0.178 & 0.443 & 0.476 & -0.441 & 0.582 \\
\hline & $(0.253)$ & $(0.260)$ & $(0.397)$ & $(0.257)$ & $(0.388)$ & $(0.375)$ & $(0.504)$ & $(0.392)$ & $(0.349)$ & $(0.483)$ & $(0.467)$ & $(0.410)$ \\
\hline Domestic expenditures & $0.212 *$ & $0.234 * *$ & $0.220^{*}$ & 0.00509 & 0.195 & $0.272^{*}$ & 0.260 & -0.0776 & $0.290 * *$ & 0.214 & 0.123 & 0.00353 \\
\hline per PLHIV (log, 3-year lag) & $(0.107)$ & $(0.107)$ & $(0.116)$ & $(0.176)$ & $(0.156)$ & $(0.151)$ & $(0.165)$ & $(0.361)$ & $(0.140)$ & $(0.195)$ & $(0.153)$ & $(0.378)$ \\
\hline \multirow[t]{2}{*}{ Squared GDP p.c. (log) } & $-0.299 * *$ & & & & -0.209 & & & & $-0.540 * * *$ & & & \\
\hline & $(0.125)$ & & & & $(0.182)$ & & & & $(0.164)$ & & & \\
\hline \multirow[t]{2}{*}{ Squared HIV prevalence (log) } & & 0.0258 & & & & 0.0445 & & & & -0.0306 & & \\
\hline & & $(0.0302)$ & & & & $(0.0415)$ & & & & $(0.0534)$ & & \\
\hline \multirow[t]{2}{*}{ Squared governement effectiveness } & & & -0.205 & & & & 0.0544 & & & & $-0.672 *$ & \\
\hline & & & $(0.294)$ & & & & $(0.404)$ & & & & $(0.374)$ & \\
\hline Squared domestic expenditures & & & & 0.0298 & & & & 0.0426 & & & & 0.0205 \\
\hline per PLHIV (log, 3-year lag) & & & & $(0.0224)$ & & & & $(0.0405)$ & & & & $(0.0423)$ \\
\hline \multirow[t]{2}{*}{ Constant } & -8.083 & $9.749 * * *$ & $9.061 * * *$ & $9.737 * * *$ & -3.377 & $9.112^{* * *}$ & $8.480 * * *$ & $9.128 * * *$ & $-19.63 * *$ & $8.483^{* * *}$ & $8.368 * * *$ & $9.251 * * *$ \\
\hline & $(6.817)$ & $(1.555)$ & (1.411) & $(1.464)$ & $(10.61)$ & $(2.207)$ & $(1.977)$ & $(2.189)$ & $(9.551)$ & $(2.839)$ & $(1.832)$ & $(2.289)$ \\
\hline Observations & 84 & 84 & 84 & 84 & 84 & 84 & 84 & 84 & 84 & 84 & 84 & 84 \\
\hline R-squared & 0.237 & 0.189 & 0.187 & 0.193 & & & & & & & & \\
\hline
\end{tabular}

* $p<0.10,{ }^{* *} p<0.05, * * * p<0.01$. Standard errors in parentheses (robust standard errors in Columns (1) to (4))

\section{Appendix Table A.15. Non-linear relationships with variables of interest}




\begin{tabular}{|c|c|c|c|c|c|c|}
\hline & (1) & (2) & (3) & (4) & (5) & (6) \\
\hline & \multicolumn{6}{|c|}{ International expenditures for HIV per PLHIV (log) } \\
\hline & \multirow{2}{*}{\multicolumn{2}{|c|}{ OLS }} & \multicolumn{4}{|c|}{ Quantile regressions } \\
\hline & & & $q(50)$ & $q(50)$ & $q(75)$ & $\mathrm{q}(75)$ \\
\hline \multirow[t]{2}{*}{ GDP p.c. (log) } & $-0.671 * * *$ & $-0.725 * * *$ & $-0.509 *$ & $-0.421 *$ & $-0.732 * *$ & $-0.867 * * *$ \\
\hline & $(0.213)$ & $(0.189)$ & $(0.260)$ & $(0.236)$ & $(0.283)$ & $(0.281)$ \\
\hline \multirow[t]{2}{*}{ HIV prevalence (log) } & -0.107 & -0.112 & -0.0506 & -0.0529 & -0.124 & -0.0186 \\
\hline & $(0.0770)$ & $(0.0759)$ & $(0.111)$ & $(0.0975)$ & $(0.121)$ & $(0.117)$ \\
\hline \multirow[t]{2}{*}{ Governement effectiveness } & 0.203 & 0.220 & 0.315 & 0.395 & 0.571 & $0.823 * *$ \\
\hline & $(0.259)$ & $(0.257)$ & $(0.377)$ & $(0.347)$ & $(0.410)$ & $(0.411)$ \\
\hline Domestic expenditures & $0.245^{* *}$ & $0.296 * * *$ & $0.254^{*}$ & $0.228^{*}$ & 0.154 & 0.245 \\
\hline per PLHIV (log, 3-year lag) & $(0.109)$ & $(0.100)$ & $(0.151)$ & $(0.133)$ & $(0.164)$ & $(0.166)$ \\
\hline \multirow[t]{2}{*}{ Constant } & $9.039 * * *$ & $9.281^{* * *}$ & $8.171^{* * *}$ & $7.713 * * *$ & $9.352 * * *$ & $10.81 * * *$ \\
\hline & $(1.414)$ & $(1.278)$ & $(1.896)$ & $(1.698)$ & $(2.063)$ & $(2.012)$ \\
\hline Outliers & Yes & No & Yes & No & Yes & No \\
\hline Observations & 84 & 82 & 84 & 81 & 84 & 80 \\
\hline R-squared & 0.181 & 0.259 & & & & \\
\hline
\end{tabular}

$* p<0.10, * * p<0.05, * * * p<0.01$. Standard errors in parentheses (robust standard errors in Columns (1) and (2))

Appendix Table A.16. Without outliers. Observations are defined as outliers when the absolute value their standardized residuals is above 2. 


\begin{tabular}{|c|c|c|c|c|c|c|}
\hline & (1) & (2) & (3) & (4) & (5) & (6) \\
\hline & \multicolumn{6}{|c|}{ International expenditures for HIV per PLHIV (log) } \\
\hline & \multirow{2}{*}{\multicolumn{2}{|c|}{ OLS }} & \multicolumn{4}{|c|}{ Quantile regressions } \\
\hline & & & & IV & & IV \\
\hline & & & $q(50)$ & $q(50)$ & $q(75)$ & $q(75)$ \\
\hline \multirow[t]{2}{*}{ GDP p.c. (log) } & $-0.671 * * *$ & $-0.597 * *$ & $-0.509 *$ & $-0.595^{* *}$ & $-0.705^{* *}$ & $-0.620 * *$ \\
\hline & $(0.213)$ & $(0.227)$ & $(0.260)$ & $(0.234)$ & $(0.288)$ & $(0.278)$ \\
\hline \multirow[t]{2}{*}{ HIV prevalence (log) } & -0.107 & $-0.312 *$ & -0.0506 & -0.134 & -0.125 & -0.405 \\
\hline & $(0.0770)$ & $(0.174)$ & $(0.111)$ & $(0.208)$ & $(0.122)$ & $(0.247)$ \\
\hline \multirow[t]{2}{*}{ Governement effectiveness } & 0.203 & 0.183 & 0.315 & 0.0199 & 0.519 & 0.147 \\
\hline & $(0.259)$ & $(0.322)$ & $(0.377)$ & $(0.360)$ & $(0.443)$ & $(0.427)$ \\
\hline Domestic expenditures & $0.245^{* *}$ & 0.153 & $0.254^{*}$ & $0.306^{* *}$ & 0.134 & 0.0419 \\
\hline per PLHIV (log, 3-year lag) & $(0.109)$ & $(0.163)$ & $(0.151)$ & $(0.134)$ & $(0.171)$ & $(0.159)$ \\
\hline Constant & $\begin{array}{c}9.039 * * * \\
(1.414)\end{array}$ & $\begin{array}{c}7.775^{* * *} \\
(1.641)\end{array}$ & $\begin{array}{c}8.171^{* * *} \\
(1.896)\end{array}$ & $\begin{array}{l}8.071^{* * *} \\
(2.220)\end{array}$ & $\begin{array}{l}9.156^{* * *} \\
(2.100)\end{array}$ & $\begin{array}{l}7.209 * * * \\
(2.631)\end{array}$ \\
\hline Observations & 84 & 80 & 84 & 80 & 80 & 80 \\
\hline R-squared & 0.181 & 0.127 & & & & \\
\hline
\end{tabular}

$* p<0.10, * * p<0.05, * * * p<0.01$. Standard errors in parentheses (robust standard errors in Columns (1) and (2))

Appendix Table A.17. IV Quantile regressions, following the method proposed by Chernozhukov and Hansen (2008) and implemented by Kwak (2014) 
H. Detailed results of the normative approach with international expenditures for HIV per PLHIV

\begin{tabular}{|c|c|c|c|c|c|c|}
\hline & (1) & (2) & (3) & (4) & (5) & (6) \\
\hline & International & $\begin{array}{l}\text { xpenditures for } \\
\text { IV }\end{array}$ & Predicte & value (exp) & $\begin{array}{l}\text { Potential in } \\
\text { international e }\end{array}$ & $\begin{array}{l}\text { crease in } \\
\text { xpenditures }\end{array}$ \\
\hline Country & $\begin{array}{l}\text { per PLHIV } \\
\text { (US\$) }\end{array}$ & (million US\$) & $\begin{array}{l}\text { per PLHIV } \\
\text { (US\$) }\end{array}$ & (million US\$) & per PLHIV (US\$) & (million US\$) \\
\hline Cameroon & 72.7 & 43.38 & 191.6 & 114.00 & 118.9 & 70.90 \\
\hline Ghana & 142.1 & 39.89 & 236.6 & 66.40 & 94.5 & 26.50 \\
\hline Thailand & 64.8 & 30.09 & 98.9 & 45.90 & 34.1 & 15.90 \\
\hline Chad & 73.3 & 12.71 & 145.2 & 25.20 & 71.9 & 12.50 \\
\hline Mali & 132.3 & 15.45 & 225.6 & 26.30 & 93.3 & 10.90 \\
\hline Pakistan & 92.1 & 6.27 & 235.8 & 16.10 & 143.6 & 9.78 \\
\hline Benin & 240.4 & 15.92 & 361.9 & 24.00 & 121.5 & 8.05 \\
\hline Madagascar & 71.0 & 2.97 & 231.1 & 9.69 & 160.2 & 6.71 \\
\hline Colombia & 2.4 & 0.30 & 50.8 & 6.32 & 48.4 & 6.02 \\
\hline Togo & 134.1 & 14.90 & 177.2 & 19.70 & 43.1 & 4.79 \\
\hline Uzbekistan & 174.5 & 7.26 & 289.6 & 12.00 & 115.1 & 4.78 \\
\hline Angola & 43.5 & 12.27 & 49.9 & 14.10 & 6.4 & 1.80 \\
\hline Malaysia & 24.3 & 2.46 & 30.5 & 3.08 & 6.1 & 0.62 \\
\hline Sri Lanka & 176.0 & 0.55 & 279.5 & 0.87 & 103.5 & 0.32 \\
\hline Mauritania & 183.2 & 2.69 & 204.4 & 3.01 & 21.3 & 0.31 \\
\hline Algeria & 47.9 & 0.38 & 79.2 & 0.62 & 31.3 & 0.25 \\
\hline Gabon & 9 & 0.44 & 10 & 0.46 & 0.49 & 0.02 \\
\hline South Africa & 58 & 376.40 & 58 & 376.00 & 0.00 & 0.00 \\
\hline Zimbabwe & 166 & 216.10 & 166 & 216.00 & 0.00 & 0.00 \\
\hline Philippines & 227 & 5.70 & 227 & 5.70 & 0.00 & 0.00 \\
\hline
\end{tabular}

Appendix Table A.18. Results from the normative approach with international expenditures per PLHIV 
References of the Appendix

Chernozhukov, V., \& Hansen, C. (2008). Instrumental variable quantile regression: A robust inference approach. Journal of Econometrics, 142(1), 379-398.

Fan, V., Silverman, R., Duran, D., \& Glassman, A. (2013). The Financial Flows of PEPFAR: A Profile. CGD Policy Paper 027. Washington DC: Center for Global Development.

Kwak, D. W. (2014). Instrumental variable quantile regression model for endogenous treatment effect. Mimeo. Michigan State University.

Söderbom, Måns, et al. (2015). Empirical development economics. New-York (US): Routledge. 